\title{
STUDI POTENSI SUMBER-SUMBER PENDANAAN PENINGKATAN KAPASITAS YANG BERKELANJUTAN PADA PEMERINTAH KABUPATEN TAPANULI TENGAH
}

\author{
Binsar Sihombing, SE, M.Si
}

\begin{abstract}
Study Potential Sources of Funding Sustainable Capacity Building in Central Tapanuli the financial activities related to the capacity of the funding process. This study will address issues of potential sources of funding local government capacity building and prediction of local revenue sources based on the potential of Central Tapanuli. This study aims to determine and analyze the relationship of GDP to the sources of local revenues, which are used as guidelines for sustainable capacity building funding. This study is intended to be the sources of funding capacity can be estimated from the period 2010-2015.
\end{abstract}

\section{PENDAHULUAN}

Peningkatan kuantitas dan kualitas pelayanan publik di daerah merupakan salah satu tujuan dari pembangunan daerah. Pelaku atau agen penting dalam pembangunan daerah adalah Pemerintah Daerah dan agen-agen pembangunan lainnya. Sebagai agen penting dalam pembangunan daerah, pemerintah daerah senantiasa meningkatkan sumber dana pembangunan daerah, khususnya sumber-sumber pendanaan peningkatan kapasitas yang berkelanjutan.

Undang-Undang N0. 32 tahun 2009 tentang Pemerintahan Daerah dan Undang-Undang Nomor 33 tahun 2009 tentang Perimbangan Keuangan Pemerintah Pusat dan Pemerintah Daerah merupakan bukti nyata perubahan yang terjadi pada organisasi pemerintah. Transformasi politik dan sosio-ekonomi dari otonomi daerah telah melahirkan tantangan baru pada pemerintah daerah. Salah satu konsekuensi dari undang-undang tersebut adalah pemerintahan otonomi dituntut untuk lebih kreatif dan inovatif menciptakan sumbersumber pendanaan guna mempertahankan kapasitas pemerintah daerah yang berkelanjutan.

Potensi sumber-sumber pendanaan peningkatan kapasitas yang berkelanjutan merupakan objek utama dari peningkatan Pendapatan Daerah. Mengingat keterbatasan alokasi dana untuk setiap kegiatan maka pemerintah daerah perlu melaksanakan analisis terhadap sumber-sumber pendanaan untuk kapasitas yang berkelanjutan. Otonomi daerah berarti memberikan kewenangan yang lebih luas bagi daerah untuk mengelola sumber daya yang dimiliki, disisi lain daerah harus mengandalkan potensi daerah untuk meningkatkan kapasitas pemerintah daerah yang berkelanjutan. Kewenangan sepenuhnya dalam menggali potensi daerah terletak pada kemampuan pemerintah daerah untuk meningkatkan sumbersumber Pendapatan Daerah.

Komponen Pendapatan Daerah berdasarkan potensi daerah terdiri dari: (1) Pendapatan Asli Daerah, (2) Bagi Hasil Pajak, (3) Bagi Hasil Bukan Pajak, dan (4) Bagian Lain-Lain Penerimaan Yang Sah. Pos-pos Pendapatan Asli Daerah terdiri dari: (1) Pajak Daerah, Retribusi Daerah, (2) Bagian Laba BUMD, dan (3) Lain-Lain Pendapatan Asli Daerah Yang Sah. Di lain pihak, pos-pos Bagi Hasil Pajak terdiri dari: (1) Pajak Bumi dan Bangunan, (2) Bea Perolehan Hak Atas Tanah dan Bangunan, (3) Pajak Penghasilan Pasal 21, dan (4) Bagi Hasil Pajak Kendaraan di Atas Air.

Pos-pos Bagi Hasil Bukan Pajak terdiri dari: (1) Sumber Daya Alam Kehutanan, (2) Sumber Daya Alam Penambangan Umum, (3) Sumber Daya Alam Perikanan, (4) Sumber Daya Alam Minyak Bumi, (5) Sumber Daya Alam Gas Bumi, dan (6) Bagi Hasil Cukai Tembakau. Pospos Bagian Lain-Lain Penerimaan Yang Sah terdiri dari: (1) Pajak Kendaraan Bermotor/Bea Balik Nama Kendaraan Bermotor, (2) Pajak Bahan Bakar Kendaraan Bermotor, (3) Pajak 
Pengambilan dan Pemanfaatan ABT dan APU, (4) Bantuan Keuangan dari Provinsi, dan (5) Hibah dari Pemprovsu.

Studi Potensi Sumber-Sumber Pendanaan Peningkatan Kapasitas Yang Berkelanjutan merupakan salah satu studi guna mempertahankan dan meningkatkan kapasitas pemerintah daerah yang berkelanjutan. Studi ini akan menetapkan kuantitas dan jenis-jenis sumber pendanaan bagi keberlangsungan program peningkatan kapasitas pemerintah daerah. Mengingat keterbatasan alokasi dana untuk setiap kegiatan, pemerintah daerah perlu melaksanakan analisis terhadap potensi sumber-sumber pendanaan untuk kapsitas yang berkelanjutan di Kabupaten Tapanuli Tengah.

Dari latar belakang Studi Potensi Sumber-Sumber Pendanaan Peningkatan Kapasitas Yang Berkelanjutan muncul beberapa permasalahan dalam merealisasikan potensi pendapatan daerah. Permasalahan dari studi ini terdiri dari: (1) Bagaimana usaha pemerintah daerah untuk meningkatkan dan merealisasikan sumber-sumber pendanaan peningkatan kapasitas pemerintah daerah Kabupaten Tapanuli Tengah. (2) Seberapa besar peningkatan pendapatan daerah sebagai sumber-sumber pendanaan kapasitas pemerintah daerah Kabupaten Tapanuli Tengah ditargetkan pada periode waktu 2010-2015.

Penelitian ini dimaksudkan untuk menganalisis sumber-sumber pendanaan daerah yang potensial guna membiayai kapasitas yang berkelanjutan. Secara khusus, studi ini bertujuan untuk menganalisis: (1) Faktor-faktor penyebab rendahnya realisasi pendapatan daerah Kabupaten Tapanuli Tengah. (2) Faktor-faktor yang mempengaruhi peningkatan realisasi pendapatan daerah sebagai sumber-sumber pendanaan kapasitas pemerintah daerah yang berkelanjutan. (3) Kuantitas peningkatan pendapatan daerah sebagai sumber-sumber peningkatan pendanaan kapasitas pemerintah daerah Kabupaten Tapanuli Tengah dari periode waktu 2010-2015.

\section{Kerangka Konseptual}

\section{Struktur Anggaran Pendapatan Daerah}

Peraturan perundang-undangan tentang otonomi daerah yang tertuang dalam UndangUndang Nomor 32 Tahun 2003 tentang Pemerintahan Daerah dan Undang-Undang Nomor 33 Tahun 2004 tentang Perimbangan Keuangan antara Pemerintah Pusat dan Daerah, pemerintah daerah terus berusaha meningkatkan kapasitas untuk meningkatkan pelayanan publik. Di bidang keuangan, beberapa pilar pokok dalam Pengelolaan Keuangan Daerah adalah Peraturan Menteri Dalam Negeri Nomor 13 Tahun 2006 tentang Pedoman Pengelolaan Keuangan Daerah. Menurut Peraturan Menteri Dalam Negeri Nomor 13 Tahun 2006, struktur APBD merupakan satu kesatuan yang terdiri dari Pendapatan Daerah, Belanja Daerah dan Pembiayaan Daerah.

Pendapatan Daerah adalah hak daerah yang diakui sebagai penambah nilai kekayaan bersih dalam periode tahun bersangkutan dan tidak perlu dibayar kembali oleh daerah. Pendapatan daerah meliputi semua penerimaan uang melalui Rekening Kas Umum Daerah yang menambah ekuitas dana. Pendapatan Daerah meliputi: Pendapatan Asli Daerah, Bagi Hasil Pajak, Bagi Hasil Bukan Pajak, Bagian Lain-Lain Penerimaan Yang Sah, Dana Alokasi Umum dan Dana Alokasi Khusus (Megantara, Iskandar dan Slamet, 2006).

Pendapatan Asli Daerah [PAD] adalah bagian dari pendapatan daerah yang bersumber dari potensi daerah itu sendiri yang dipungut berdasarkan peraturan daerah sesuai dengan peraturan perundang-undangan yang berlaku. Kewenangan daerah dalam memungut PAD dimaksudkan agar daerah dapat mendanai pelaksanaan otonomi daerah yang bersumber dari potensi daerahnya sendiri. PAD terdiri dari Pajak Daerah, Retribusi Daerah, Bagian 
Laba BUMD dan Lain-Lain PAD Yang Sah (Mardiasmo, 2002; Mulyana, Subkhan dan Slamet. 2006).

Pajak Daerah terdiri dari: (1) Pajak Hotel, (2) Pajak Restoran, (3) Pajak Hiburan, (4) Pajak Reklame, (5) Pajak Penerangan, dan (6) Pajak Pengambilan dan Pengolahan Galian Golongan C. Retribusi Daerah terdiri dari: (1) Retribusi Pelayanan Kesehatan, (2) Retribusi Pelayanan Persampahan, (3) Retribusi Penggantian Biaya Cetak KTP dan Akte Catatan Sipil, (4) Retribusi Parkir di Tepi Jalan Umum, (5) Retribusi Pasar, (6) Retribusi Pemeriksaan Alat Pemadam Kebakaran, (7) Retribusi Pengujian dan Registrasi Kapal Perikanan, (8) Retribusi Pemakaian Kekayaan Daerah, (9) Retribusi Pasar Grosir dan Pertokoan, (10) Retribusi Rumah Potong Hewan, (11) Retribusi Jasa Usaha Pelayanan Pelabuhan, (12) Retribusi Tempat Rekreasi dan Olah Raga, (13) Retribusi Penjualan Produksi Usaha Daerah, (14) Retribusi Izin Mendirikan Bangunan, (15) Retribusi Izin Gangguan, (16) Retribusi Izin Trayek Oto, (17) Retribusi Izin Usaha Angkutan, (18) Retribusi Pendaftaran dan SIM Becak Dayung, (19) Retribusi Pendaftaran dan SIM Becak Bermotor, (20) Retribusi Pengujian dan Pengawasan Perlindungan Ketenagakerjaan Perusahaan, (21) Retribusi Peruntukan Pengguna Tanah, (22) Retribusi Pengawasan dan Pemeriksaan, Pemanfaatan, Penimbunan Kayu Hasil Hutan dan Tanah Milik, (23) Retribusi Izin Usaha Perdagangan dan Pendaftaran Perusahaan, (24) Retribusi Surat Izin Jasa Konstruksi Kecil, Sedang dan Besar, (25) Retribusi Pembangunan Hasil Tera Ulang Alat Ukur, Takar, Timbang dan BDKT, (26) Retribusi Tempat Penjualan Minuman Beralkohol, (27) Retribusi Izin dan Pengelolaan Sarang Burung Walet, dan (28) Retribusi Pengujian Kendaraan Bermotor. Bagian Laba BUMD terdiri dari: (1) Lembaga Keuangan Bank [PT. Bank Sumut], dan (2) Penyertaan Modal Investasi Kepada Pihak Ketiga. Lain-Lain PAD Yang Sah terdiri dari: (1) Hasil Penjualan Aset Daerah Yang Tidak Dipisahkan/Lelang, (2) Jasa Giro, (3) Denda Keterlambatan Penyerahan Pekerjaan, (4) Sumbangan Pihak Ketiga, (5) Pemberian Hak Atas Tanah Negara, (6) Pendapatan dari Pengembalian Dana Bergulir, dan (7) Penerimaan Potongan dari PT. Taspen.

Bagi Hasil Pajak terdiri dari: (1) Pajak Bumi dan Bangunan, (2) Bea Perolehan Hak Atas Tanah dan Bangunan, (3) Pajak Penghasilan Pasal 21, dan (4) Bagi Hasil Pajak Kendaraan Diatas Air. Bagi Hasil Bukan Pajak terdiri dari: (1) Sumber Daya Alam Kehutanan, (2) Sumber Daya Alam Penambangan Umum, (3) Sumber Daya Alam Perikanan, (4) Sumber Daya Alam Minyak Bumi, (5) Sumber Daya Alam Gas Bumi, dan (6) Bagi Hasil Cukai Tembakau.

Bagian Lain-Lain Penerimaan Yang Sah terdiri dari: (1) Pajak Kendaraan Bermotor/Bea Balik Nama Kendaraan Bermotor, (2) Pajak Kendaraan Bahan Bakar Bermotor, (3) Pajak Pengambilan dan Pemanfaatan ABT dan APU, (4) Bantuan Keuangan dari Provinsi, dan (5) Hibah dari Provinsi.

Dana Perimbangan merupakan bagian yang tidak dapat dipisahkan dari struktur APBD, namun tidak dapat sepenuhnya digunakan sebagai ukur kinerja Pendapatan Daerah, karna bagian Dana Perimbangan ini lebih merupakan bantuan atau subsidi dari Pemerintah Pusat. Dana Perimbangan terdiri dari Dana Alokasi Umum dan Dana Alokasi Khusus. Oleh sebab itu Pendapatan Daerah yang bersumber dari Dana Perimbangan tidak menjelaskan potensi sumber-sumber pendanaan peningkatan kapasitas pemerintah daerah yang berkelanjutan.

\section{Faktor Penentu Pendapatan Daerah}

Standar formal anggaran pendapatan dan belanja daerah dapat menggambarkan perubahan kebijakan fiskal pemerintahan pusat dan pemerintahan daerah. Integrasi kebijakan fiskal pemerintah pusat dengan keuangan pemerintahan daerah akan mempengaruhi aktifitas ekonomi sektoral dan daerah. Standar formal anggaran pemerintahan daerah yang 
disederhanakan terdiri dari berbagai fungsi pendapatan dan belanja. Integrasi kebijakan fiskal pemerintahan pusat terhadap keuangan pemerintahan daerah menjelaskan peranan pemerintah pusat dan pemerintahan daerah dalam penentuan aktifitas ekonomi daerah.

Kendala anggaran pemerintahan daerah merupakan keseimbangan antara total pendapatan dengan total belanja pemerintahan daerah. Perubahan aktiva atau kewajiban dan ekuitas pemerintahan daerah merupakan perubahan surplus atau defisit anggaran. Oleh sebab itu kendala anggaran pemerintahan daerah dan perubahan aktiva atau kewajiban dan ekuitas pemerintahan daerah masing-masing adalah

$$
\begin{aligned}
& \mathrm{BD}+\mathrm{R} \times \mathrm{SDD}=\mathrm{PD}+\partial \mathrm{SDD} / \partial \mathrm{t} \\
& \partial \mathrm{SDD} / \partial \mathrm{t}=\mathrm{BD}+\mathrm{R} \times \mathrm{SDD}-\mathrm{PD}
\end{aligned}
$$

dimana:

$$
\begin{aligned}
\mathrm{R} \times \mathrm{SDD}= & \text { pembayaran bunga hutang atau pendapatan bunga pinjaman } \\
& \text { pemerintahan daerah [Juta Rp], } \\
\mathrm{BD}= & \text { Belanja Daerah [Juta Rp], } \\
\mathrm{PD} \quad= & \text { Pendapatan Daerah ]Juta Rp], dan } \\
\partial \mathrm{SDD} / \partial \mathrm{t} & =\quad \text { Perubahan Kewajiban/Aktiva Pemerintah Daerah [Juta Rp]. }
\end{aligned}
$$

Surplus anggaran adalah peningkatan aktiva pemerintahan daerah, sebaliknya defisit anggaran adalah peningkatan kewajiban pemerintahan daerah. No-Ponzi game condition menyatakan bahwa utilitas marginal dari aktiva atau kewajiban dan ekuitas pemerintahan daerah sampai waktu takterhingga sama dengan nol, yaitu:

$$
\operatorname{Lim} \operatorname{SDD}(z) \mathrm{e}^{\int_{\mathrm{R}}(\mathrm{u}) \mathrm{du}}
$$

Integral dari $\operatorname{Lim} \operatorname{SDD}(z) \mathrm{e}^{\jmath} \mathrm{R}(\mathrm{u})$ du dengan kendala $\partial \mathrm{SDD} / \partial \mathrm{t}$ menghasilkan aktiva atau kewajiban pemerintahan daerah, yaitu:

$$
\operatorname{SDD}=\int[B D(z)+R \times S D D-P D(z)] e^{\int} R(u) d u d z
$$

Kendala dan surplus atau defisit anggaran pemerintahan daerah menjelaskan intertemporal budget constraint (Blanchard and Fischer, 1989; Romer, 1996). Intertemporal budget constraint menyatakan bahwa nilai berjalan kewajiban pemerintahan daerah harus sama dengan nilai sekarang dari surplus anggaran. Artinya intertemporal budget constraint tidak mengimplikasikan bahwa kewajiban pemerintahan daerah pada akhirnya akan dibayar atau aktiva pemerintahan daerah pada akhirnya akan diterima.

Respons pendapatan asli daerah dan penerimaan pajak dan bukan pajak di daerah terhadap tingkat pajak dan output daerah adalah positif, sebaliknya respons terhadap tingkat bunga adalah negatif. Peningkatan stok modal pisik daerah dan produksi daerah akan meningkatkan pendapatan asli daerah dan penerimaan pajak dan bukan pajak di daerah. Identitas pendapatan daerah berdasarkan potensi daerah adalah penjumlahan pendapatan asli daerah dengan bagi hasil pajak, bagi hasil bukan pajak dan lain-lain penerimaan yang sah. Oleh sebab itu Pendapatan Daerah dirumuskan sebagai berikut:

$$
\mathrm{PED}=\mathrm{PAD}+\mathrm{BHP}+\mathrm{BBP}+\mathrm{LRS}
$$

dimana:

$$
\begin{aligned}
& \text { PED }=\text { Pendapatan Daerah [Juta Rp] } \\
& \text { PAD }=\text { Pendapatan Asli Daerah [Juta Rp] } \\
& \text { BHP }=\text { Bagi Hasil Pajak [Juta Rp], } \\
& \text { BBP }=\text { Bagi Hasil Bukan Pajak [Juta Rp], dan } \\
& \text { LPS }=\text { Lain-Lain Penerimaan Yang Sah [Juta Rp] } .
\end{aligned}
$$

Faktor ekonomi penting penentu Pendapatan Daerah adalah PDRB, artinya peningkatan PDRB akan meningkatkan Pendapatan Daerah (Doepke, Lehnert and Sellgren, 1998). 
Pendapatan Asli Daerah merupakan penjumlahan dari Pajak Daerah dengan Retribusi Daerah, Bagian Laba BUMD dan Lain-Lain PAD Yang Sah. Oleh sebab itu identitas pendapatan asli daerah dirumuskan sebagai berikut:

PAD = PJD + RTD + LBU + LPS

dimana:

PJD = Pajak Daerah [Juta Rp],

RTD = Retribusi Daerah [Juta Rp],

LBU = Laba BUMD [Juta Rp], dan

LPS = Lain-Lain PAD Yang Sah [Juta Rp].

Faktor ekonomi penting penentu Pendapatan Asli Daerah adalah PDRB, artinya peningkatan PDRB akan meningkatkan Pendapatan Asli Daerah (Doepke, Lehnert and Sellgren, 1998; Blanchard, 2000).

Pajak Daerah merupakan penjumlah dari Pajak Hotel [PED01] dengan Pajak Restoran [PED02], Pajak Hiburan [PED03], Pajak Reklame [PED04], Pajak Penerangan [PED05], Pajak Pengambilan dan Pengolahan Galian Golongan C [PED06]. Oleh sebab itu identitas Pajak Daerah dirumuskan sebagai berikut:

PJD = PED01 + PED02 + PED03 + PED04 + PED05 + PED06

Faktor ekonomi penting penentu Pajak Daerah adalah PDRB, artinya peningkatan PDRB akan meningkatkan Pajak Daerah (Doepke, Lehnert and Sellgren, 1998; Blanchard, 2000; Blanchard and Fischer. 1989).

Retribusi Daerah terdiri dari: (1) Retribusi Pelayanan Kesehatan [PED07], (2) Retribusi Pelayanan Persampahan [PED08], (3) Retribusi Penggantian Biaya Cetak KTP dan Akte Catatan Sipil [PED09], (4) Retribusi Parkir di Tepi Jalan Umum [PED10], (5) Retribusi Pasar [PED11], (6) Retribusi Pemeriksaan Alat Pemadam Kebakaran [PED12], (7) Retribusi Pengujian dan Registrasi Kapal Perikanan [PED13], (8) Retribusi Pemakaian Kekayaan Daerah [PED14], (9) Retribusi Pasar Grosir dan Pertokoan [PED15], (10) Retribusi Rumah Potong Hewan [PED16], (11) Retribusi Jasa Usaha Pelayanan Pelabuhan [PED17], (12) Retribusi Tempat Rekreasi dan Olah Raga [PED18], (13) Retribusi Penjualan Produksi Usaha Daerah [PED19], (14) Retribusi Izin Mendirikan Bangunan [PED20], (15) Retribusi Izin Gangguan [PED21], (16) Retribusi Izin Trayek Oto [PED22], (17) Retribusi Izin Usaha Angkutan [PED23], (18) Retribusi Pendaftaran dan SIM Becak Dayung [PED24], (19) Retribusi Pendaftaran dan SIM Becak Bermotor [PED25], (20) Retribusi Pengujian dan Pengawasan Perlindungan Ketenagakerjaan Perusahaan [PED26], (21) Retribusi Peruntukan Pengguna Tanah [PED27], (22) Retribusi Pengawasan dan Pemeriksaan, Pemanfaatan, Penimbunan Kayu Hasil Hutan dan Tanah Milik [PED28], (23) Retribusi Izin Usaha Perdagangan dan Pendaftaran Perusahaan [PED29], (24) Retribusi Surat Izin Jasa Konstruksi Kecil, Sedang dan Besar [PED30], (25) Retribusi Pembangunan Hasil Tera Ulang Alat Ukur, Takar, Timbang dan BDKT [PED31], (26) Retribusi Tempat Penjualan Minuman Beralkohol [PED32], (27) Retribusi Izin dan Pengelolaan Sarang Burung Walet [PED33], dan (28) Retribusi Pengujian Kendaraan Bermotor [PED34]. Retribusi Daerah dirumuskan sebagai berikut:

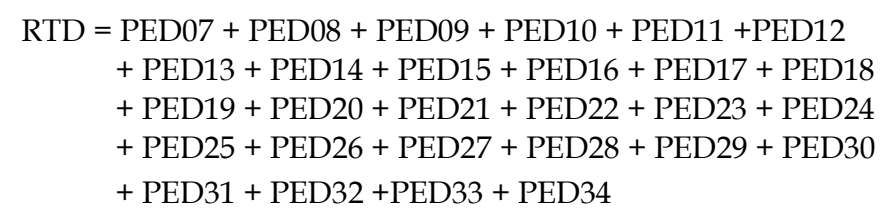

Faktor ekonomi penting penentu Retribusi Daerah adalah PDRB, artinya peningkatan PDRB akan meningkatkan Retribusi Daerah (Barro, 1997; Barro and Sala-I-Martin. 1995). 
Bagian Laba BUMD terdiri dari: (1) PT. Bank Sumut [PED35], dan (2) Penyertaan Modal Investasi Kepada Pihak Ketiga [PED36]. Bagian Laba BUMD dirumuskan sebagai berikut:

$$
\text { LBU }=\text { PED35 + PED36 }
$$

Faktor ekonomi penting penentu Bagian Laba BUMD adalah PDRB, artinya peningkatan PDRB akan meningkatkan Bagian Laba BUMD (Barro, 1997; Barro and Sala-I-Martin. 1995).

Lain-Lain PAD Yang Sah terdiri dari: (1) Hasil Penjualan Aset Daerah Yang Tidak Dipisahkan/Lelang [PED37], (2) Jasa Giro [PED38], (3) Denda Keterlambatan Penyerahan Pekerjaan [PED38], (4) Sumbangan Pihak Ketiga [PED40], (5) Pemberian Hak Atas Tanah Negara [PED41], (6) Pendapatan dari Pengembalian Dana Bergulir [PED42], dan (7) Penerimaan Potongan dari PT. Taspen [PED43]. Lain-Lain PAD Yang Sah dirumuskan sebagai berikut:

$$
\begin{aligned}
\mathrm{LPS}= & \text { PED37 + PED38 + PED39 + PED40 + PED41 + PED42 } \\
& + \text { PED43 }
\end{aligned}
$$

Faktor ekonomi penting penentu Lain-Lain PAD Yang Sah adalah PDRB, artinya peningkatan PDRB akan meningkatkan Lain-Lain PAD Yang Sah (Blanchard. and Summers. 1984).

Bagi Hasil Pajak terdiri dari: (1) Pajak Bumi dan Bangunan [PED44], (2) Bea Perolehan Hak Atas Tanah dan Bangunan [PED45], (3) Pajak Penghasilan Pasal 21 [PED46], dan (4) Bagi Hasil Pajak Kendaraan di Atas Air [PED47]. Oleh sebab itu Bagi Hasil Pajak dirumuskan sebagai berikut:

$$
\mathrm{BHP}=\text { PED44 + PED45 + PED46 + PED47 }
$$

Faktor ekonomi penting penentu Bagi Hasil Pajak adalah PDRB, artinya peningkatan PDRB akan meningkatkan Bagi Hasil Pajak (Blanchard. and Summers. 1984; Dornbusch, Fischer and Startz. 1998).

Bagi Hasil Bukan Pajak terdiri dari (1) Sumber Daya Alam Kehutanan [PED48], (2) Sumber Daya Alam Penambangan Umum [PED49], (3) Sumber Daya Alam Perikanan [PED50], (4) Sumber Daya Alam Minyak Bumi [PED51], (5) Sumber Daya Alam Gas Bumi [PED52], dan (6) Bagi Hasil Cukai Tembakau [PED53]. Oleh sebab itu Bagi Hasil Bukan Pajak dirumuskan sebagai berikut:

$$
\text { BBP = PED48 + PED49 + PED50 + PED51 + PED52 + PED53 }
$$

Faktor ekonomi penting penentu Bagi Hasil Bukan Pajak adalah PDRB, artinya peningkatan PDRB akan meningkatkan Bagi Hasil Bukan Pajak (Dornbusch, Fischer and Startz. 1998; Harberger, 1998).

Bagian Lain-Lain Penerimaan Yang Sah terdiri dari: (1) Pajak Kendaraan Bermotor/Bea Balik Nama Kendaraan Bermotor [PED54], (2) Pajak Kendaraan Bahan Bakar Bermotor [PED55], (3) Pajak Pengambilan dan Pemanfaatan ABT dan APU [PED56], (4) Bantuan Keuangan dari Provinsi [PED57], dan (5) Hibah dari Provinsi [PED58]. Bagian Lain-Lain Penerimaan Yang Sah dirumuskan sebagai berikut:

$$
\text { LRS }=\text { PED54 + PED55 + PED56 + PED57 + PED58 }
$$

Faktor ekonomi penting penentu Bagian Lain-Lain Penerimaan Yang Sah adalah PDRB, artinya peningkatan PDRB akan meningkatkan Bagian Lain-Lain.

\section{METODE PENELITIAN}

Sumber data utama yang dipergunakan dalam penelitian ini adalah data sekunder dan informasi lain yang berkaitan dengan topik penelitian. Oleh sebab itu disain penelitian yang digunakan adalah studi data sekunder (Zikmund, 1997). Sumber data sekunder merupakan data yang diperoleh dari Tapanuli Tengah Dalam Angka dan Dinas Pendapatan Daerah. Sumber data sekunder lainnya adalah buku-buku, hasil penelitian, peraturan-peraturan dan perundang-undangan yang berhubungan dengan penelitian. 
Skala pengukuran data dalam penelitian ini adalah skala rasio, yaitu data mempunyai sifat rasio atau ratio, jarak atau range dan peringkat atau natural ordering (Greene, 1997; Gujarati, 2003; Manurung, Manurung dan Saragih, 2005; Pindyck and Rubinfeld, 1991). Metode analisis data menggunakan analisis panel dari pos-pos pendapatan daerah. Komponen panel dari Pendapatan Daerah adalah

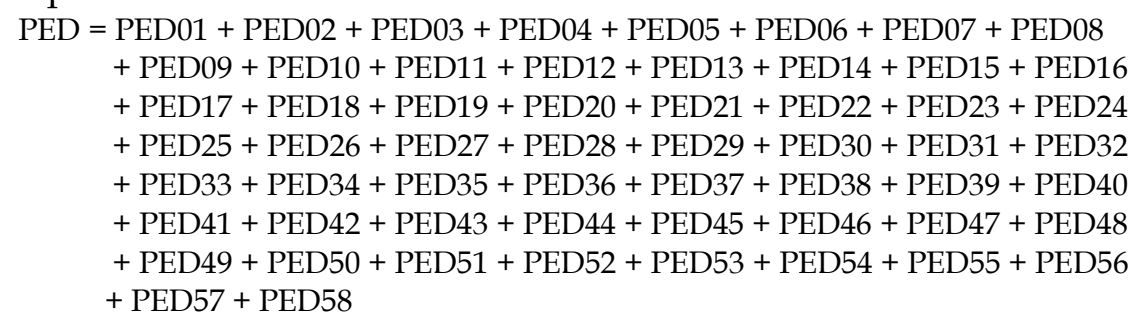

Metode analisis yang digunakan dalam penelitian ini adalah metode pertumbuhan lin-log, yaitu metode pertumbuhan yang menjelaskan bahwa semua komponen pendapatan daerah [PED] bertumbuh secara kontinu sejalan dengan pertumbuhan Produk Domestik Regional Bruto [PDRB], sehingga model prediksi pendapatan daerah dirumuskan dalam bentuk model lin-log (Gujarati, 2003; Manurung, Manurung dan Saragih, 2005), yaitu:

$\mathrm{PED}=\ln \beta_{0}+\beta_{1} \ln \mathrm{PDRB}+\varepsilon$

dimana koefisien $\beta_{1}$ menjelaskan koefisien PDRB. Elastisitas PDRB terhadap berbagai komponen Pendapatan Daerah adalah

$$
\begin{aligned}
\mathrm{E}_{\mathrm{PDRB}} & =[\partial \mathrm{PED} / \partial \mathrm{PDRB}][\mathrm{PDRB} / \mathrm{PED}] \\
& =\beta_{1}: \mathrm{PED}_{\mathrm{it}}
\end{aligned}
$$

Koefisien elastisitas ini menjelaskan bahwa semakin tinggi PED maka semakin rendah elastisitas PDRB terhadap masing-masing komponen pendapatan daerah. Model ini sesuai dengan konsep otonomi daerah, dimana percepatan pertumbuhan ekonomi daerah akan mempercepat peningkatan pendapatan daerah. Persamaan di atas digunakan untuk memprediksi potensi masing-masing komponen Pendapatan Daerah dari periode 2010-2015 pada asumsi pertumbuhan PDRB tertentu. Model panel dari Pendapatan Daerah adalah

PED $=\beta_{0}+\beta_{1} \ln$ PDRB $+\mu_{\mathrm{i}}+\varepsilon_{\mathrm{it}}$

dimana $\mathrm{i}=01,02, \ldots, 58, \mathrm{t}=2003,2004, \ldots, 2009, \beta_{0}+\mu_{\mathrm{i}}$ adalah pengaruh tetap atau fixed effect, $\mu_{\mathrm{i}}$ adalah pengaruh acak atau random effect dari komponen Pendapatan Daerah dan $\varepsilon_{\mathrm{it}}$ adalah residual dari komponen Pendapatan Daerah dan runtun waktu 2003-2009. Efek tetap menjelaskan efek khusus pos-pos pendapatan daerah, seperti efek perubahan teknologi, efek perubahan regulasi pemerintah atau efek perubahan eksternal lainnya, sedangkan efek acak menjelaskan karaketeristik kejutan acak dari observasi pos-pos pendapatan daerah yang konstan sepanjang waktu atau unocservable or latent variable (Manurung, Manurung dan Saragih, 2005). Nilai pengaruh tetap ini kurang lebih menjelaskan penjumlahan efek acak masing-masing komponen Pendapatan Daerah dengan konstanta bersama. Pengaruh tetap 
menjelaskan potensi tertinggi sumber-sumber pendanaan peningkatan kapasitas yang berkelanjutan.

Proyeksi atau peramalan PDRB dari tahun 2010-2015 menggunakan model trend eksponensial, yaitu:

$$
\ln \mathrm{PDRB}=\ln \imath_{0}+\imath_{1} \ln \mathrm{TIME}+\varepsilon_{\mathrm{t}}
$$

dimana $t_{0}$ dan $\imath_{1}$ masing-masing adalah parameter dan TIME $=2003: 1,2004: 2, \ldots$, 2015:12. Nilai prediksi PDRB dari tahun 2010-2015 digunakan untuk memprediksi pendapatan daerah [PED] dari tahun 2010-2015. Metode estimasi yang digunakan adalah generalized least square [GLS] dengan asumsi bahwa residual $[\varepsilon]$ terdistribusi secara normal dan nonautokorelasi.

\section{Hasil Analisis dan Pembahasan}

Hasil studi data sekunder mengungkapkan bahwa pendapatan daerah naik sejalan dengan peningkatan PDRB Kabupaten Tapanuli Tengah. Asosiasi antara pendapatan daerah [PED] dengan PDRB berdasarkan harga berlaku, proyeksi PDRB dan PED dari tahun 2010-2015. Dari tahun 2003-2009, rata-rata pendapatan daerah [PED] sebesar 2.83 persen dari PDRB. Rasio pendapatan daerah terhadap PDRB atau tax ratio ini sangat rendah atau jauh lebih rendah dari rasio pajak atau tax ratio nasional. Hal ini mengindikasikan bahwa realisasi potensi pendapatan daerah belum dapat dioptimalkan.

Dari tahun 2003-2009, rerata pertumbuhan pendapatan daerah sebesar 16.07 persen, sedangkan rerata pertumbuhan PDRB atas dasar harga berlaku sebesar 9.82 persen. Tingginya pertumbuhan pendapatan daerah dibandingkan dengan pertumbuhan PDRB tersebut mengindikasikan potensi pendapatan daerah yang relatif tinggi. Potensi peningkatan PDRB akan mengindikasikan potensi pendapatan daerah, dimana model prediksi PDRB Kabupaten Tapanuli Tengah dengan trend eksponensial adalah:

\section{ln PDRB = 20.73450 + 0.314806 ln TIME}

dimana model proyeksi PDRB ini signifikan pada tingkat $\alpha=1.00$ persen. Hasil proyeksi PDRB dan pendapatan daerah [PED] dari tahun 2010-2015 atas dasar harga berlaku sebesar Rp 1.990.000.000.000 pada tahun 2009 diproyeksikan naik menjadi Rp 4.020.000.000.000 atau rerata naik sebesar 11.72 persen per tahun.

Model potensi pos-pos pendapatan daerah [PED] sebagai fungsi dari PDRB ditunjukkan pada Tabel 1. Model lin-log dengan random effect model sesuai untuk pendaparan daerah. Model ini mempunyai konstanta bersama negatip Rp 24.717.710.600 dan koefisien ln PDRB terhadap PED sebesar 1.206.673.460 yang masing-masing signifikansi pada tingkat $\alpha=1$ persen. Nilai kontanta bersama [C] ditambah random effect merupakan fixed effect dari 58 pospos pendapatan daerah. Fixed effect paling tinggi mengindikasikan potensi paling tinggi dari pos-pos pendapatan daerah sebagai sumber pendanaan peningkatan kapasitas yang berkelanjutan di Kabupaten Tapanuli Tengah.

\section{Tabel 1}

Hasil Estimasi Model Potensi Pos-Pos Pendapatan Daerah [PED] Kabupaten Tapanuli Tengah

\begin{tabular}{|crrrr|}
\hline Variable & Coefficient & Std. Error & t-Statistic & Prob. \\
\hline C & -24717710.600 & 5851248.096 & -4.2244 & 0.0000 \\
LOG(PDRB) & 1206673.460 & 276888.842 & 4.3580 & 0.0000 \\
Random Effects & & & & \\
01--C & -710187.842 & & & \\
02--C & -689153.134 & & \\
03--C & -716933.960 & & \\
04--C & -636759.667 & & \\
\hline
\end{tabular}




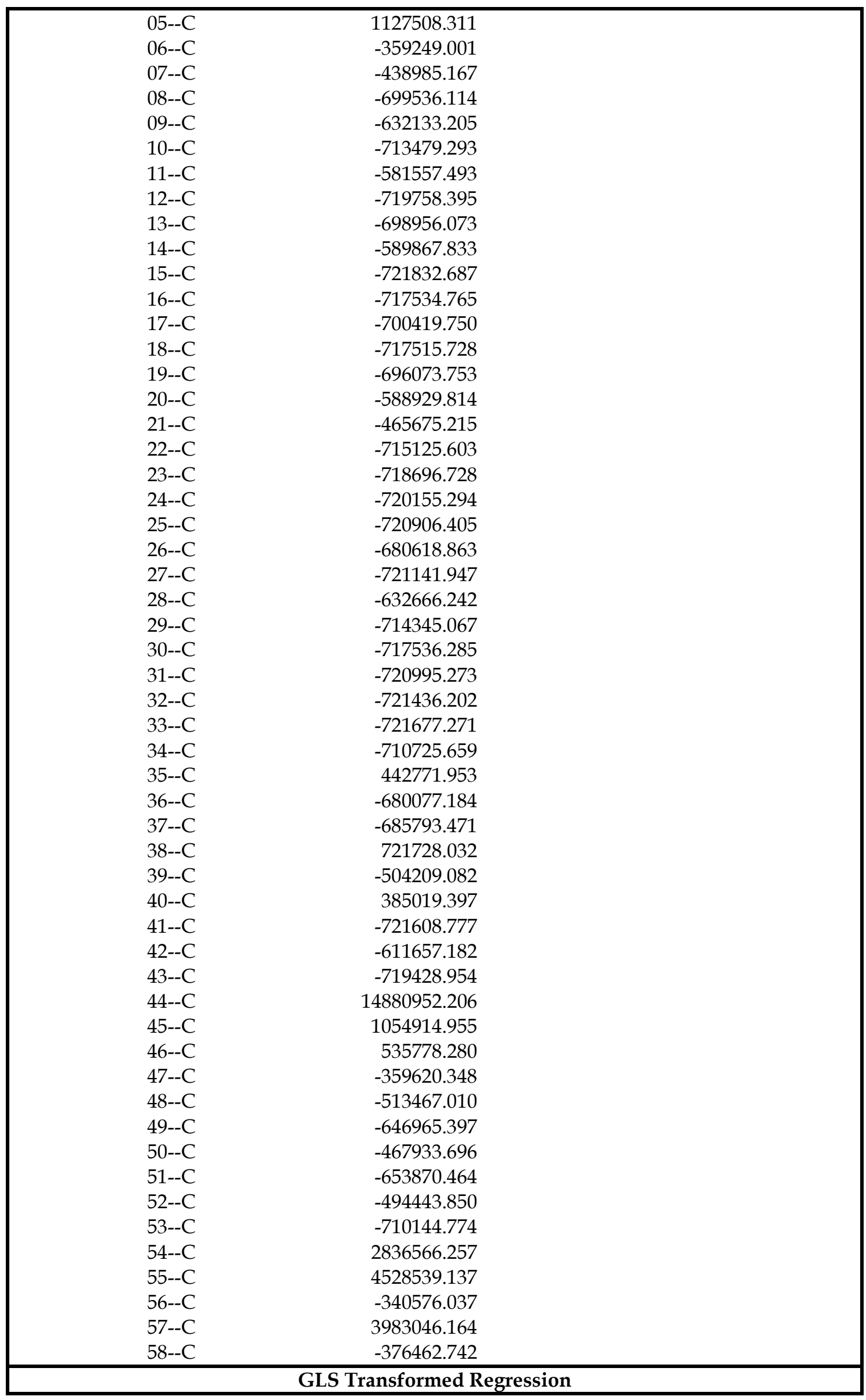




\begin{tabular}{|lrlr|}
\hline R-squared & 0.8048 & Mean dependent var & 746438.3975 \\
Adjusted R-squared & 0.8043 & S.D. dependent var & 2549720.5884 \\
S.E. of regression & 1127839.1335 & Sum squared resid & $5.139 \mathrm{E}+14$ \\
Durbin-Watson stat & 1.2604 & & \\
\hline & Unweighted Statistics including Random Effects & \\
\hline R-squared & 0.8310 & Mean dependent var & 746438.3975 \\
Adjusted R-squared & 0.8306 & S.D. dependent var & 2549720.5884 \\
S.E. of regression & 1049328.589 & Sum squared resid & $4.448 \mathrm{E}+14$ \\
Durbin-Watson stat & 1.4560 & & \\
\hline
\end{tabular}

Sumber: Data diolah dengan EViews 4.

Hasil studi data sekunder menunjukkan sumber-sumber pendapatan sebagai potensi pendanaan peningkatan kapasitas yang berkelanjutan terdiri dari Pajak Daerah, Retribusi Daerah, Bagian Laba Badan Usaha Milik Daerah, Lain-lain PAD Yang Sah, Bagi Hasil Pajak, Bagi Hasil Bukan Pajak dan Bagian Lain-lain Penerimaan Yang Sah. Dari tahun 2003-2009, rata-rata pajak daerah yang bersumber dari pajak penerangan jalan [PED05] diikuti oleh pajak pengambilan dan pengolahan galian golongan $C$ [PED06] sebesar 94.60 persen. Artinya hanya sebesar 5.40 persen pajak daerah bersumber dari pajak hotel [PED01], pajak restoran [PED02], pajak hiburan [PED03] dan pajak reklame [PED04]. Pos-pos pajak daerah terdiri dari pajak hotel, pajak restoran, pajak hiburan, pajak reklame, pajak penerangan jalan dan pajak pengambilan dan pengolahan galian golongan $C$. Hasil estimasi pos-pos pajak daerah adalah sebagai berikut:

$\begin{array}{ll}\text { PED01 } & =-710187.842-24717710.600+1206673.460 \text { In PDRB } \\ \text { PED02 } & =-689153.134-24717710.600+1206673.460 \text { In PDRB } \\ \text { PED03 } & -716933.960-24717710.600+1206673.460 \text { In PDRB } \\ \text { PED04 } & =-636759.667-24717710.600+1206673.460 \text { In PDRB } \\ \text { PED05 } & 1127508.311-24717710.600+1206673.460 \text { In PDRB } \\ \text { PED06 } & -359249.001-24717710.600+1206673.460 \text { In PDRB } \\ \text { PJD } & =\text { PED01+ PED02+ PED03 + PED04 + PED05 + PED06 }\end{array}$

Dari persamaan ini diketahui bahwa komponen random effect dari pajak penerangan jalan [PED05] lebih tinggi dari komponen random effect pajak pengambilan dan pengolahan galian golongan C [PED06], pajak reklame [PED04], pajak restoran [PED02], pajak hotel [PED01] dan pajak hiburan [PED03]. Artinya pengaruh khusus pos-pos pendapatan daerah, perubahan teknologi, perubahan regulasi pemerintah dan perubahan eksternal mengindikasikan bahwa potensi pajak penerangan jalan lebih tinggi dibandingkan dengan potensi pajak pengambilan dan pengolahan galian golongan $\mathrm{C}$, pajak restoran, pajak hotel dan pajak hiburan. Rerata elastisitas pajak hotel, pajak restoran, pajak hiburan, pajak reklame, pajak penerangan jalan dan pajak pengambilan dan pengolahan galian golongan $\mathrm{C}$ terhadap PDRB masing-masing sebesar 28.60 persen, 19.35 persen, 34.39 persen, 10.56 persen, 0.65 persen dan 3.08 persen. Artinya persentase peningkatan PDRB lebih rendah dari persentase peningkatan pajak hotel, pajak restoran, pajak hiburan, pajak reklame dan pajak pengambilan dan pengolahan galian golongan $C$. kecuali pajak penerangan jalan. Hal ini mengindikasikan bahwa potensi pos-pos pajak daerah masih tinggi sejalan dengan dengan peningkatan potensi PDRB Kabupaten Tapanuli Tengah.

\section{Tabel 2}

Perkembangan dan Proyeksi Pajak Daerah [PJD]: PED01, PED02, PED03, PED04, PED05 dan PED06 Kabupaten Tapanuli Tengah [Ribu Rp]

\begin{tabular}{|c|rrrrrr|r|}
\hline TAHUN & PED01 & PED02 & PED03 & PED04 & PED05 & PED06 & PJD \\
\hline 2003 & 10672.000 & 10672.000 & 400.000 & 23622.500 & 1302953.000 & 294575.900 & 1642895.400 \\
2004 & 13503.600 & 13503.600 & 555.000 & 35088.000 & 1498986.000 & 245657.400 & 1807293.600 \\
2005 & 10230.000 & 23684.000 & 250.000 & 50585.250 & 1501639.000 & 222500.100 & 1808888.350 \\
2006 & 7420.000 & 34055.500 & 15180.000 & 58865.120 & 1199962.000 & 280786.400 & 1596269.020 \\
2007 & 10893.500 & 67046.950 & 5670.000 & 116307.100 & 2600864.000 & 488349.400 & 3289130.950 \\
2008 & 10375.750 & 33930.550 & 7770.000 & 157686.600 & 2392172.000 & 613409.400 & 3215344.300 \\
2009 & 21197.700 & 53662.100 & 5635.000 & 173656.300 & 2890090.000 & 479325.100 & 3623566.200 \\
\hline
\end{tabular}




\begin{tabular}{|r|rrrrrr|r|}
2010 & 32213.219 & 80322.707 & 8616.824 & 250991.397 & 3173768.770 & 617322.606 & 4163235.523 \\
2011 & 40588.373 & 100576.239 & 10878.507 & 308981.058 & 3377981.012 & 716468.753 & 4555473.942 \\
2012 & 46331.813 & 114287.194 & 12428.163 & 348595.030 & 3501480.378 & 787427.935 & 4810550.513 \\
2013 & 51462.504 & 126867.812 & 13817.705 & 386001.832 & 3695232.350 & 856524.195 & 5129906.398 \\
2014 & 57505.061 & 141316.169 & 15445.396 & 428149.900 & 3840511.135 & 929804.342 & 5412732.003 \\
2015 & 64615.950 & 158506.707 & 17373.488 & 476607.930 & 3975758.445 & 1013595.659 & 5706458.179 \\
\hline
\end{tabular}

Sumber: Data diolah dari Tapanuli Tengah Dalam Angka. BPS Kabupaten Tapanuli Tengah, 2003-2009 dan proyeksi dengan EViews 4.

Perkembangan dan proyeksi pajak hotel [PED01], pajak restoran [PED02], pajak hiburan [PED03], pajak reklame [PED04], pajak penerangan jalan [PED05] dan pajak pengambilan dan pengolahan galian golongan C [PED06] masing-masing memberikan kontribusi terhadap pajak daerah [PJD] sebesar 0.73 persen, 1.83 persen, 0.24 persen, 5.15 persen, 76.12 persen dan 15.93 persen. Pajak daerah [PJD] sebesar Rp 3.623.566.200 pada tahun 2009 diproyeksikan naik menjadi $\operatorname{Rp} 5.706 .458 .179$ pada tahun 2015 atau rerata naik sebesar 7.57 persen per tahun. Proyeksi rerata peningkatan ini lebih rendah dari rerata peningkatan PDRB Kabupaten Tapanuli Tengah.

Pos-pos retribusi daerah terdiri dari 28 pos pendapatan, yaitu: (1) retribusi pelayanan kesehatan, (2) retribusi pelayanan persampahan, (3) retribusi penggantian biaya cetak KTP dan Akte Catatan Sipil, (4) retribusi parkir di tepi jalan umum, (5) retribusi pasar, (6) retribusi pemeriksaan alat pemadam kebakaran, (7) retribusi pengujian dan registrasi kapal perikanan, (8) retribusi pemakaian kekayaan daerah, (9) retribusi pasar grosir dan pertokoan, (10) retribusi rumah potong hewan, (11) retribusi jasa usaha pelayanan pelabuhan, (12) retribusi tempat rekreasi dan olah raga, (13) retribusi penjualan produksi usaha daerah, (14) retribusi izin mendirikan bangunan, (15) retribusi izin gangguan, (16) retribusi izin trayek oto, (17) retribusi izin usaha angkutan, (18) retribusi pendaftaran dan SIM becak dayung, (19) retribusi pendaftaran dan SIM becak bermotor, (20) retribusi pengujian dan pengawasan perlindungan ketenagakerjaan perusahaan, (21) retribusi peruntukan pengguna tanah, (22) retribusi pengawasan dan pemeriksaan, pemanfaatan, penimbunan kayu hasil hutan dan tanah milik, (23) retribusi izin usaha perdagangan dan pendaftaran perusahaan, (24) retribusi surat izin jasa konstruksi kecil, sedang dan vesar, (25) retribusi pembangunan hasil tera ulang alat ukur, takar, timbang dan BDKT, (26) retribusi rempat penjualan minuman beralkohol, (27) retribusi izin dan pengelolaan sarang burung walet, dan (28) retribusi pengujian kendaraan bermotor. Hasil estimasi pos-pos retribusi daerah adalah sebagai berikut:

PED07 $=-438985.167-24717710.600+1206673.460$ In PDRB PED08 $=-699536.114-24717710.600+1206673.460$ In PDRB PED09 $=-632133.205-24717710.600+1206673.460$ In PDRB PED10 $=-713479.293-24717710.600+1206673.460$ In PDRB PED11 $=-581557.493-24717710.600+1206673.460$ In PDRB PED12 $=-719758.395-24717710.600+1206673.460$ In PDRB PED13 $=-698956.073-24717710.600+1206673.460$ In PDRB PED14 $=-589867.832-24717710.600+1206673.460$ In PDRB PED15 $=-721832.687-24717710.600+1206673.460$ In PDRB PED16 $=-717534.765-24717710.600+1206673.460$ In PDRB PED17 $=-700419.750-24717710.600+1206673.460$ In PDRB PED18 $=-717515.728-24717710.600+1206673.460$ In PDRB PED19 $=-696073.753-24717710.600+1206673.460 \ln$ PDRB PED20 $=-588929.814-24717710.600+1206673.460 \ln$ PDRB PED21 $=-465675.215-24717710.600+1206673.460$ In PDRB PED22 $=-715125.603-24717710.600+1206673.460$ In PDRB PED23 $=-718696.728-24717710.600+1206673.460$ In PDRB PED24 $=-720155.294-24717710.600+1206673.460$ In PDRB PED25 $=-720906.405-24717710.600+1206673.460$ In PDRB PED26 $=-680618.863-24717710.600+1206673.460$ In PDRB PED27 $=-721141.947-24717710.600+1206673.460$ In PDRB PED28 $=-632666.242-24717710.600+1206673.460$ In PDRB PED29 $=-714345.067-24717710.600+1206673.460$ In PDRB 


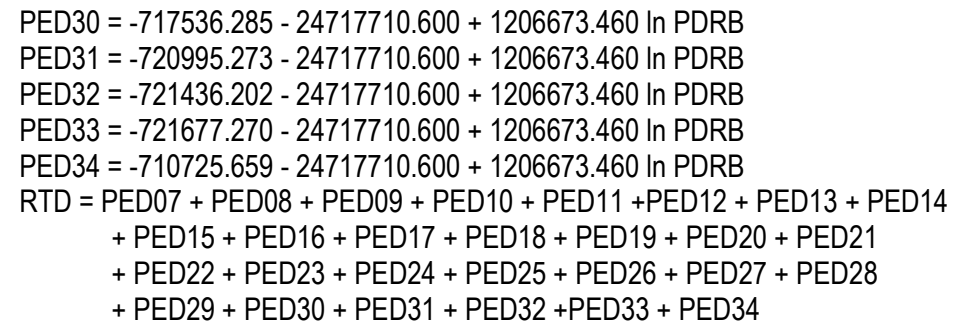

Dari persamaan ini diketahui bahwa komponen random effect dari retribusi pelayanan kesehatan [PED07] lebih tinggi dari komponen random retribusi izin gangguan [PED21], retribusi pasar [PED11], retribusi izin mendirikan bangunan [PED20], retribusi pemakaian kekayaan daerah [PED14], retribusi penggantian biaya cetak KTP dan Akte Catatan Sipil [PED09], retribusi pengawasan dan pemeriksaan, pemanfaatan, penimbunan kayu hasil hutan dan tanah milik [PED28], retribusi pengujian dan pengawasan perlindungan ketenagakerjaan perusahaan [PED26], retribusi penjualan produksi usaha daerah [PED19], retribusi pengujian dan registrasi kapal perikanan [PED13].

Komponen random effect dari retribusi pengujian dan registrasi kapal perikanan lebih tinggi dari komponen random effect retribusi pelayanan persampahan [PED08], retribusi jasa usaha pelayanan pelabuhan [PED17], retribusi pengujian kendaraan bermotor [PED34], retribusi parkir di tepi jalan umum [PED10], retribusi izin usaha perdagangan dan pendaftaran perusahaan [PED29], retribusi izin trayek oto [PED22], retribusi tempat rekreasi dan olah raga [PED18], retribusi rumah potong hewan [PED16], retribusi surat izin jasa konstruksi kecil, sedang dan besar [PED30], retribusi izin usaha angkutan [PED23], retribusi pemeriksaan alat pemadam kebakaran [PED12], retribusi pendaftaran dan SIM becak dayung [PED24], retribusi pendaftaran dan SIM becak bermotor [PED25], retribusi pembangunan hasil tera ulang alat ukur, takar, timbang dan BDKT [PED31], retribusi peruntukan pengguna tanah [PED27], retribusi tempat penjualan minuman beralkohol [PED32], retribusi izin dan pengelolaan sarang burung walet [PED33] dan retribusi pasar grosir dan pertokoan [PED15]. Artinya pengaruh khusus pos-pos retribusi daerah, perubahan teknologi, perubahan regulasi pemerintah dan perubahan eksternal mengindikasikan bahwa potensi retribusi pelayanan kesehatan lebih tinggi dibandingkan dengan potensi retribusi izin gangguan, retribusi pasar, retribusi izin mendirikan bangunan, retribusi pemakaian kekayaan daerah, retribusi penggantian biaya cetak KTP dan Akte Catatan Sipil, retribusi pengawasan dan pemeriksaan, pemanfaatan, penimbunan kayu hasil hutan dan tanah milik, retribusi pengujian dan pengawasan perlindungan ketenagakerjaan perusahaan, tetribusi penjualan produksi usaha daerah, retribusi pengujian dan registrasi kapal perikanan dan retribusi pelayanan persampahan.

Pengaruh khusus pos-pos retribusi daerah, perubahan teknologi, perubahan regulasi pemerintah dan perubahan eksternal mengindikasikan bahwa potensi retribusi pelayanan persampahan lebih tinggi dibandingkan dengan potensi retribusi jasa usaha pelayanan pelabuhan, retribusi pengujian kendaraan bermotor, retribusi parkir di tepi jalan umum, retribusi izin usaha perdagangan dan pendaftaran perusahaan, retribusi izin trayek oto, retribusi tempat rkreasi dan oah raga, retribusi rumah potong hewan, retribusi surat izin jasa konstruksi kecil, sedang dan besar, retribusi izin usaha angkutan, retribusi pemeriksaan alat pemadam kebakaran, retribusi pendaftaran dan SIM becak dayung, retribusi pendaftaran dan SIM becak bermotor, retribusi pembangunan hasil tera ulang alat ukur, takar, timbang dan BDKT, retribusi peruntukan pengguna tanah, retribusi tempat penjualan minuman beralkohol, retribusi izin dan pengelolaan sarang burung walet dan retribusi pasar grosir dan pertokoan. 
Rerata elastisitas retribusi pelayanan kesehatan [PED07], retribusi pelayanan persampahan [PED08], retribusi penggantian biaya cetak KTP dan Akte Catatan Sipil [PED09], retribusi parkir di tepi jalan umum [PED10], retribusi pasar [PED11], retribusi pemeriksaan alat pemadam kebakaran [PED12] dan retribusi pengujian dan registrasi kapal perikanan [PED13] terhadap PDRB masing-masing sebesar 3.89 persen, 23.08 persen, 10.15 persen, 31.26 persen, 7.12 persen, 37.29 persen dan 22.72 persen. Artinya persentase peningkatan PDRB selalu lebih rendah dari persentase peningkatan retribusi pelayanan kesehatan, retribusi pelayanan persampahan, retribusi penggantian biaya cetak KTP dan Akte Catatan Sipil, retribusi parkir di tepi jalan umum, retribusi pasar, retribusi pemeriksaan alat pemadam kebakaran dan retribusi pengujian dan registrasi kapal perikanan atau bersifat elastis. Hal ini mrngindikasikan bahwa potensi pos-pos retribusi daerah ini masih tinggi sejalan dengan dengan peningkatan potensi PDRB Kabupaten Tapanuli Tengah.

Tabel 3

Perkembangan dan Proyeksi Retribusi Daerah [RTD]: PED07, PED08. PED09, PED10, PED11, PED12 dan PED13 Kabupaten Tapanuli Tengah [Ribu Rp]

\begin{tabular}{|c|rrrrrrr|}
\hline TAHUN & PED07 & PED08 & PED09 & PED10 & PED11 & PED12 & PED13 \\
\hline 2003 & 164012.600 & 11425.000 & 53878.500 & 5030.000 & 89090.700 & 3000.000 & 15000.000 \\
2004 & 164254.800 & 10226.000 & 39614.000 & 5350.000 & 101090.800 & 3000.000 & 15500.000 \\
2005 & 171417.000 & 10260.300 & 51350.000 & 5500.000 & 101499.500 & 3000.000 & 15000.000 \\
2006 & 297227.600 & 17046.000 & 53817.000 & 3700.000 & 136594.700 & 3000.000 & 15000.000 \\
2007 & 351578.700 & 33187.500 & 78211.000 & 5800.000 & 181234.000 & 600.000 & 25217.000 \\
2008 & 360431.800 & 33264.000 & 143263.500 & 17445.000 & 194910.000 & 100.000 & 45700.000 \\
2009 & 538501.800 & 45987.500 & 229166.000 & 17642.000 & 210978.400 & 2315.000 & 34178.000 \\
2010 & 708438.568 & 69333.759 & 329387.316 & 26894.628 & 295262.900 & 3547.262 & 51519.156 \\
2011 & 837817.331 & 87045.269 & 405567.218 & 33909.712 & 358676.555 & 4483.452 & 64619.304 \\
2012 & 921966.676 & 99164.739 & 457538.086 & 38733.858 & 401770.518 & 5125.742 & 73654.216 \\
2013 & 1008947.324 & 110122.937 & 505803.324 & 43046.228 & 442467.226 & 5698.324 & 81762.827 \\
2014 & 1102570.823 & 122898.100 & 562180.532 & 48118.605 & 488101.835 & 6372.981 & 91245.399 \\
2015 & 1207123.493 & 137902.079 & 624390.474 & 54074.259 & 541599.646 & 7169.558 & 102376.636 \\
\hline
\end{tabular}

Sumber: Data diolah dari Tapanuli Tengah Dalam Angka. BPS Kabupaten Tapanuli Tengah, 2003-2009 dan proyeksi dengan EViews 4.

Perkembangan dan proyeksi retribusi pelayanan kesehatan [PED07], retribusi pelayanan persampahan [PED08], retribusi penggantian biaya cetak KTP dan Akte Catatan Sipil [PED09], retribusi parkir di tepi jalan umum [PED10], retribusi pasar [PED11], retribusi pemeriksaan alat pemadam kebakaran [PED12] dan retribusi pengujian dan registrasi kapal perikanan [PED13] masing-masing memberikan kontribusi terhadap retribusi daerah [RTD] sebesar 21.07 persen, 1.88 persen, 8.06 persen, 0.72 persen, 10.05 persen, 0.16 persen dan 1.68 persen.

Persamaan di atas juga menunjukkan rerata elastisitas retribusi pemakaian kekayaan daerah [PED14], retribusi pasar grosir dan pertokoan [PED15], retribusi rumah potong hewan [PED16], retribusi jasa usaha pelayanan pelabuhan [PED17], retribusi tempat rekreasi dan olah raga [PED18], retribusi penjualan produksi usaha daerah [PED19] dan retribusi izin mendirikan bangunan [PED20] terhadap PDRB masing-masing sebesar 7.52 persen, 39.85 persen, 35.89 persen, 23.36 persen, 34.86 persen, 21.41 persen dan 7.40 persen. Artinya persentase peningkatan PDRB selalu lebih rendah dari persentase peningkatan retribusi pemakaian kekayaan daerah, retribusi pasar grosir dan pertokoan, retribusi rumah potong hewan, retribusi jasa usaha pelayanan pelabuhan, retribusi tempat rekreasi dan olah raga, retribusi penjualan produksi usaha daerah dan retribusi izin mendirikan bangunan atau bersifat elastis. Hal ini mengindikasikan bahwa potensi pos-pos retribusi daerah ini masih tinggi sejalan dengan dengan peningkatan potensi PDRB Kabupaten Tapanuli Tengah. 
Tabel 4

Perkembangan dan Proyeksi Retribusi Daerah [RTD]: PED14, PED15, PED16, PED17, PED18, PED19 dan PED20 Kabupaten Tapanuli Tengah [Ribu Rp]

\begin{tabular}{|c|rrrrrrr|}
\hline TAHUN & PED14 & PED15 & PED16 & PED17 & PED18 & PED19 & PED20 \\
\hline 2003 & 53068.500 & 0.000 & 4000.000 & 20000.000 & 7500.000 & 95000.000 & 191438.500 \\
2004 & 51490.000 & 0.000 & 4000.000 & 20000.000 & 7500.000 & 0.000 & 71402.870 \\
2005 & 63373.000 & 0.000 & 4000.000 & 20000.000 & 0.000 & 3000.000 & 166175.900 \\
2006 & 52946.250 & 0.000 & 4000.000 & 20000.000 & 1670.000 & 22000.000 & 80554.300 \\
2007 & 174456.500 & 0.000 & 7000.000 & 25000.000 & 4218.800 & 15000.000 & 100095.200 \\
2008 & 236983.000 & 0.000 & 6111.000 & 25000.000 & 360.000 & 36959.000 & 178817.800 \\
2009 & 322925.500 & 0.000 & 2000.000 & 25000.000 & 10000.000 & 14500.000 & 173548.200 \\
2010 & 453777.446 & 10407.640 & 3059.613 & 37711.240 & 15286.937 & 21782.153 & 243751.682 \\
2011 & 552162.949 & 13496.700 & 3863.511 & 47357.685 & 19308.308 & 27324.312 & 297171.181 \\
2012 & 619259.140 & 27986.100 & 4415.545 & 53976.690 & 22068.270 & 31193.080 & 334337.499 \\
2013 & 684082.061 & 40106.300 & 4908.237 & 59898.560 & 24526.740 & 34511.648 & 366500.363 \\
2014 & 756921.276 & 62382.700 & 5487.155 & 66847.937 & 27427.234 & 38567.662 & 406225.793 \\
2015 & 836634.192 & 78589.200 & 6172.037 & 75053.684 & 30846.985 & 43251.053 & 449614.367 \\
\hline
\end{tabular}

Sumber: Data diolah dari Tapanuli Tengah Dalam Angka. BPS Kabupaten Tapanuli Tengah, 2003-2009 dan proyeksi dengan EViews 4.

Perkembangan dan proyeksi retribusi pemakaian kekayaan daerah [PED14], retribusi pasar grosir dan pertokoan [PED15], retribusi rumah potong hewan [PED16], retribusi jasa usaha pelayanan pelabuhan [PED17], retribusi tempat rekreasi dan olah raga [PED18], retribusi penjualan produksi usaha daerah [PED19] dan retribusi izin mendirikan bangunan [PED20] masing-masing memberikan kontribusi terhadap retribusi daerah sebesar 11.13 persen, 0.35 persen, 0.24 persen, 1.51 persen, 0.41 persen, 1.43 persen dan 9.25 persen.

Persamaan di atas menunjukkan rerata elastisitas retribusi izin gangguan [PED21], retribusi izin trayek oto [PED22], retribusi izin usaha angkutan [PED23], retribusi pendaftaran dan SIM becak dayung [PED24], retribusi pendaftaran dan SIM becak bermotor [PED25], retribusi pengujian dan pengawasan perlindungan ketenagakerjaan perusahaan [PED26] dan retribusi peruntukan pengguna tanah [PED27] terhadap PDRB masing-masing sebesar 4.25 persen, 32.65 persen, 36.15 persen, 37.73 persen, 38.72 persen, 16.89 persen dan 38.96 persen. Artinya persentase peningkatan PDRB selalu lebih rendah dari persentase peningkatan retribusi izin gangguan, izin trayek oto, retribusi izin usaha angkutan, retribusi pendaftaran dan SIM becak dayung, retribusi pendaftaran dan SIM becak bermotor, retribusi pengujian dan pengawasan perlindungan ketenagakerjaan perusahaan dan retribusi peruntukan pengguna tanah atau bersifat elastis. Hal ini mengindikasikan bahwa potensi pos-pos retribusi daerah ini masih tinggi sejalan dengan dengan peningkatan potensi PDRB Kabupaten Tapanuli Tengah.

Perkembangan dan proyeksi retribusi izin gangguan [PED21], retribusi izin trayek oto [PED22], retribusi izin usaha angkutan [PED23], retribusi pendaftaran dan SIM becak dayung [PED24], retribusi pendaftaran dan SIM becak bermotor [PED25], retribusi pengujian dan pengawasan perlindungan ketenagakerjaan perusahaan [PED26] dan retribusi peruntukan pengguna tanah [PED27] memberikan kontribusi terhadap retribusi daerah [RTD] masing-masing sebesar 18.82 persen, 0.51 persen, 0.28 persen, 0.13 persen, 0.17 persen, 3.01 persen dan 0.38 persen.

\section{Tabel 5}

Perkembangan dan Proyeksi Retribusi Daerah [RTD]: PED21, PED22. PED23, PED24, PED25, PED26 dan PED27 Kabupaten Tapanuli Tengah [Ribu Rp]

\begin{tabular}{|c|c|c|c|c|c|c|c|}
\hline TAHUN & PED21 & PED22 & PED23 & PED24 & PED25 & PED26 & PED27 \\
\hline 2003 & 104414.100 & 6250.000 & 0.000 & 0.000 & 0.000 & 48498.000 & 1000.000 \\
\hline 2004 & 165741.900 & 5750.000 & 2500.000 & 5000.000 & 0.000 & 4359.000 & 1000.000 \\
\hline 2005 & 145572.500 & 6000.000 & 2625.000 & 1625.000 & 0.000 & 20499.000 & 1000.000 \\
\hline 2006 & 142793.300 & 6000.000 & 2625.000 & 600.000 & 0.000 & 49200.000 & 1000.000 \\
\hline
\end{tabular}




\begin{tabular}{|r|rrrrrrr|}
2007 & 355576.800 & 7500.000 & 3750.000 & 1587.000 & 0.000 & 58100.000 & 1000.000 \\
2008 & 443541.700 & 7550.000 & 4375.000 & 1000.000 & 0.000 & 56775.000 & 0.000 \\
2009 & 496584.900 & 9500.000 & 6825.000 & 2330.000 & 6705.000 & 60900.000 & 0.000 \\
2010 & 660988.632 & 14501.400 & 10449.952 & 3571.342 & 10283.823 & 90567.531 & 11108.380 \\
2011 & 781892.390 & 18299.202 & 13201.825 & 4513.841 & 13003.384 & 113087.531 & 13167.300 \\
2012 & 864904.108 & 20904.954 & 15089.293 & 5160.842 & 14868.129 & 128480.030 & 27663.800 \\
2013 & 949605.473 & 23232.010 & 16777.187 & 5738.232 & 16533.562 & 142360.019 & 40800.300 \\
2014 & 1038961.862 & 25969.321 & 18760.348 & 6417.303 & 18494.811 & 158607.664 & 62075.100 \\
2015 & 1137585.249 & 29199.228 & 21101.042 & 7220.006 & 20805.391 & 177630.035 & 78300.800 \\
\hline
\end{tabular}

Sumber: Data diolah dari Tapanuli Tengah Dalam Angka. BPS Kabupaten Tapanuli Tengah, 2003-2009 dan proyeksi dengan EViews 4.

Persamaan di atas juga menunjukkan rerata elastisitas retribusi pengawasan dan pemeriksaan, pemanfaatan dan penimbunan kayu hasil hutan dan tanah milik [PED28], retribusi izin usaha perdagangan dan pendaftaran perusahaan [PED29], retribusi surat izin jasa konstruksi kecil, sedang dan besar [PED30], retribusi pembangunan HTU, alat ukur, takar, timbang dan BDKT [PED31], retribusi tempat penjualan minuman beralkohol [PED32], retribusi izin dan pengelolaan sarang brung walet [PED33] dan retribusi pengujian kendaraan bermotor [PED34] terhadap PDRB masing-masing sebesar 9.78 persen, 32.02 persen, 34.98 persen, 38.77 persen, 39.35 persen, 39.65 persen dan 29.45 persen. Artinya persentase peningkatan PDRB selalu lebih rendah dari persentase peningkatan retribusi pengawasan dan pemeriksaan, pemanfaatan dan penimbunan kayu hasil hutan dan tanah milik, retribusi izin usaha perdagangan dan pendaftaran perusahaan, retribusi surat izin jasa konstruksi kecil, sedang dan besar, retribusi pembangunan HTU, alat ukur, takar, timbang dan BDKT, retribusi tempat penjualan minuman beralkohol, retribusi izin dan pengelolaan sarang brung walet dan retribusi pengujian kendaraan bermotor atau bersifat elastis. Hal ini mengindikasikan bahwa potensi pos-pos retribusi daerah ini masih tinggi sejalan dengan dengan peningkatan potensi PDRB Kabupaten Tapanuli Tengah.

\section{Tabel 6}

Perkembangan dan Proyeksi Retribusi Daerah [RTD]: PED28, PED29, PED30, PED31, PED32, PED33 dan PED34 Kabupaten Tapanuli Tengah [Ribu Rp]

\begin{tabular}{|c|rrrrrrrr|}
\hline TAHUN & PED28 & PED29 & PED30 & PED31 & PED32 & PED33 & PED34 & RTD \\
\hline 2003 & 320000.00 & 0.00 & 0.00 & 0.00 & 0.00 & 0.00 & 0.00 & 1192605.90 \\
2004 & 257631.70 & 0.00 & 0.00 & 0.00 & 0.00 & 0.00 & 0.00 & 935411.07 \\
2005 & 64821.07 & 3100.00 & 6000.00 & 1650.00 & 0.00 & 0.00 & 0.00 & 867468.27 \\
2006 & 2700.00 & 3300.00 & 3050.00 & 0.00 & 0.00 & 0.00 & 0.00 & 918824.15 \\
2007 & 288.75 & 18550.00 & 6950.00 & 850.00 & 2370.00 & 1125.00 & 0.00 & 1459246.25 \\
2008 & 0.00 & 21700.00 & 7900.00 & 3561.72 & 400.00 & 0.00 & 10311.75 & 1836460.27 \\
2009 & 0.00 & 7550.00 & 7200.00 & 0.00 & 100.00 & 0.00 & 70087.75 & 2294525.05 \\
2010 & 95219.43 & 11527.41 & 11017.13 & 11271.50 & 153.48 & 10595.10 & 106467.17 & 3317882.58 \\
2011 & 21349.80 & 14534.49 & 13913.01 & 13429.30 & 194.07 & 13651.10 & 134269.20 & 3921309.94 \\
2012 & 36503.20 & 16602.01 & 15898.41 & 27806.70 & 221.93 & 27138.50 & 153205.20 & 4445637.27 \\
2013 & 49077.40 & 18458.69 & 17676.26 & 40912.50 & 246.80 & 40251.00 & 170313.65 & 4944365.18 \\
2014 & 70389.00 & 20623.92 & 19762.36 & 62272.10 & 276.04 & 62535.80 & 190532.20 & 5541025.87 \\
2015 & 87747.40 & 23186.80 & 22223.73 & 78406.40 & 310.60 & 78748.80 & 213777.13 & 6171040.27 \\
\hline
\end{tabular}

Sumber: Data diolah dari Tapanuli Tengah Dalam Angka. BPS Kabupaten Tapanuli Tengah, 2003-2009 dan proyeksi dengan EViews 4.

Perkembangan dan proyeksi retribusi pengawasan dan pemeriksaan, pemanfaatan dan penimbunan kayu hasil hutan dan tanah milik [PED28], retribusi izin usaha perdagangan dan pendaftaran perusahaan [PED29], retribusi surat izin jasa konstruksi kecil, sedang dan besar [PED30], retribusi pembangunan HTU, alat ukur, takar, timbang dan BDKT [PED31], retribusi tempat penjualan minuman beralkohol [PED32], retribusi izin dan pengelolaan sarang brung walet [PED33] dan retribusi pengujian kendaraan bermotor [PED34] memberikan kontribusi terhadap retribusi daerah [RTD] masing-masing sebesar 5.39 persen, 0.44 persen, 0.34 persen, 0.38 persen, 0.02 persen, 0.35 persen dan 1.85 persen. 
Proyeksi retribusi pengawasan dan pemeriksaan, pemanfaatan dan penimbunan kayu hasil hutan dan tanah milik [PED28], retribusi izin usaha perdagangan dan pendaftaran perusahaan [PED29], retribusi surat izin jasa konstruksi kecil, sedang dan besar [PED30], retribusi pembangunan HTU, alat ukur, takar, timbang dan BDKT [PED31], retribusi izin dan pengelolaan sarang brung walet [PED33] dan retribusi daerah [RTD] mengalami peningkatan pertumbuhan, sedangkan retribusi tempat penjualan minuman beralkohol [PED32] dan retribusi pengujian kendaraan bermotor [PED34] mengalami penurunan pertumbuhan. Peningkatan pertumbuhan pos-pos retribusi daerah merupakan potensi sumber-sumber pendanaan kapasitas yang berkelanjutan di Kabupaten Tapanuli Tengah. Retribusi daerah [RTD] sebesar Rp 2.294.525.050 pada tahun 2009 diproyeksikan naik menjadi Rp 6.171.040.270 pada tahun 2015 atau rerata naik sebesar 16.49 persen per tahun. Proyeksi peningkatan ini lebih tinggi dari proyeksi peningkatan PDRB Kabupaten Tapanuli Tengah.

Pos-pos laba Badan Usaha Milik Daerah [BUMD] terdiri dari 2 [dua] pos pendapatan, yaitu pendapatan lembaga keuangan PT. Bank Sumut dan penyertaan modal investasi kepada pihak ketiga. Hasil estimasi pos-pos bagian laba BUMD adalah sebagai berikut:

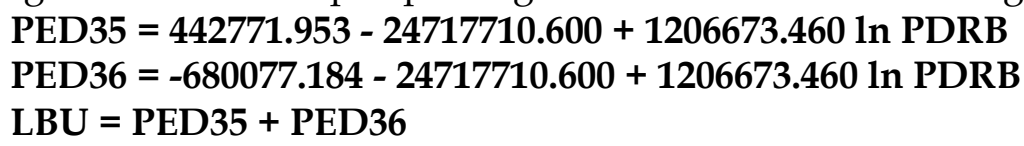

Tabel 7

Perkembangan dan Proyeksi Bagian Laba BUMD [LBU]: PED35 dan PED36 Kabupaten Tapanuli Tengah [Ribu Rp]

\begin{tabular}{|c|rrr|}
\hline TAHUN & PED35 & PED36 & LBU \\
\hline 2003 & 0.000 & 0.000 & 0.000 \\
2004 & 0.000 & 0.000 & 0.000 \\
2005 & 0.000 & 137003.800 & 137003.800 \\
2006 & 2096659.000 & 81414.400 & 2178073.400 \\
2007 & 1707452.000 & 31373.000 & 1738825.000 \\
2008 & 2263023.000 & 43360.800 & 2306383.800 \\
2009 & 2362990.000 & 9100.000 & 2372090.000 \\
2010 & 2725809.222 & 13588.914 & 2739398.136 \\
2011 & 2943453.662 & 16983.651 & 2960437.313 \\
2012 & 3044711.796 & 19250.474 & 3063962.270 \\
2013 & 3331702.095 & 21335.203 & 3353037.298 \\
2014 & 3477774.415 & 23738.959 & 3501513.374 \\
2015 & 3659408.793 & 26593.241 & 3686002.034 \\
\hline
\end{tabular}

Sumber: Data diolah dari Tapanuli Tengah Dalam Angka. BPS Kabupaten Tapanuli Tengah, 2003-2009 dan proyeksi dengan EViews 4.

Dari persamaan ini diketahui bahwa komponen random effect pendapatan dari lembaga keuangan PT. Bank Sumut [PED35] lebih tinggi dari pendapatan penyertaan modal investasi kepada pihak ketiga [PED36]. Artinya pengaruh khusus pos-pos pendapatan bagian laba BUMD, perubahan teknologi, perubahan regulasi pemerintah dan perubahan eksternal mengindikasikan bahwa potensi pendapatan dari lembaga keuangan PT. Bank Sumut lebih tinggi dari potensi pendapatan penyertaan modal investasi kepada pihak ketiga.

Rerata elastisitas pendapatan dari lembaga keuangan PT. Bank Sumut [PED35] dan pendapatan dari penyertaan modal investasi kepada pihak ketiga [PED36] terhadap PDRB masing-masing sebesar 1.03 persen dan 16.92 persen. Artinya persentase peningkatan PDRB selalu lebih rendah dari persentase peningkatan pendapatan dari lembaga keuangan PT. Bank Sumut dan pendapatan dari penyertaan modal investasi kepada pihak ketiga atau bersifat elastis. Hal ini mengindikasikan bahwa potensi pos-pos bagian laba BUMD masih tinggi sejalan dengan dengan peningkatan potensi PDRB Kabupaten Tapanuli Tengah. Perkembangan dan proyeksi potensi pos-pos bagian laba BUMD ditunjukkan pada Tabel 12 . 
Perkembangan dan proyeksi pendapatan dari lembaga keuangan PT. Bank Sumut [PED35] dan pendapatan dari penyertaan modal investasi kepada pihak ketiga [PED36] memberikan kontribusi terhadap bagian laba BUMD [LBU] masing-masing sebesar 99.41 persen dan 0.59 persen.

Pos-pos lain-lain PAD yang sah terdiri dari 7 [tujuh] pos pendapatan, yaitu hasil penjualan aset daerah yang tidak dipisahkan/lelang, jasa giro, denda keterlambatan penyerahan pekerjaan, sumbangan pihak ketiga, pemberian hak atas tanah negara, pendapatan dari pengembalian dana bergulir dan penerimaan potongan dari PT. taspen. Hasil estimasi pospos lain-lain PAD yang sah adalah sebagai berikut:

$$
\begin{aligned}
& \text { PED37 }=-685793.471-24717710.600+1206673.460 \text { In PDRB } \\
& \text { PED38 }=721728.032-24717710.600+1206673.460 \text { In PDRB } \\
& \text { PED39 }=-504209.082-24717710.600+1206673.460 \text { In PDRB } \\
& \text { PED40 }=385019.397-24717710.600+1206673.460 \text { In PDRB } \\
& \text { PED41 }=-721608.777-24717710.600+1206673.460 \text { In PDRB } \\
& \text { PED42 }=-611657.182-24717710.600+1206673.460 \text { In PDRB } \\
& \text { PED43 = -719428.954 }-24717710.600+1206673.460 \text { In PDRB } \\
& \text { LPS = PED37 + PED38 + PED39 + PED40 + PED41 + PED42 + PED43 }
\end{aligned}
$$

Dari persamaan ini diketahui bahwa komponen random effect jasa giro bank [PED38] lebih tinggi dari komponen random effect sumbangan pihak ketiga [PED40], denda keterlambatan penyerahan pekerjaan [PED39], pendapatan dan pengembalian dana bergulir [PED42], hasil penjualan asset daerah yang tidak dipisahkan/lelang [PED37], penerimaan potongan dari PT. Taspen [PED43] dan pemberian hak atas tanah negara [PED41]. Artinya pengaruh khusus dari pos-pos lain-lain PAD yang sah, perubahan teknologi, perubahan regulasi pemerintah dan perubahan eksternal mengindikasikan bahwa potensi pendapatan daerah dari jasa giro bank lebih tinggi dari sumbangan pihak ketiga, denda keterlambatan penyerahan pekerjaan, pendapatan dan pengembalian dana bergulir, hasil penjualan asset daerah yang tidak dipisahkan/lelang, penerimaan potongan dari PT. Taspen dan pemberian hak atas tanah negara.

Rerata elastisitas pendapatan dari hasil penjualan asset daerah yang tidak dipisahkan/lelang [PED37], jasa giro bank [PED38], denda keterlambatan penyerahan pekerjaan [PED39], sumbangan pihak ketiga [PED40], pemberian hak atas tanah negara [PED41], pendapatan dan pengembalian dana bergulir [PED42] dan penerimaan potongan dari PT. Taspen [PED43] terhadap PDRB masing-masing sebesar 18.28 persen, 0.82 persen, 5.06 persen, 1.06 persen 39.55 persen, 8.89 persen dan 37.05 persen. Artinya persentase peningkatan PDRB selalu lebih rendah dari persentase peningkatan hasil penjualan asset daerah yang tidak dipisahkan/lelang, denda keterlambatan penyerahan pekerjaan, sumbangan pihak ketiga, pemberian hak atas tanah negara, pendapatan dan pengembalian dana bergulir dan penerimaan potongan dari PT. Taspen atau elastis. Hal ini mengindikasikan bahwa potensi pos-pos lain-lain PAD yang sah masih tinggi sejalan dengan peningkatan potensi PDRB Kabupaten Tapanuli Tengah, kecuali peningkatan jasa giro bank bersifat inelastis terhadap PDRB. Perkembangan dan proyeksi potensi pos-pos lain-lain PAD yang sah ditunjukkan pada Tabel 13.

Perkembangan dan proyeksi pendapatan dari hasil penjualan asset daerah yang tidak dipisahkan/lelang [PED37], jasa giro bank [PED38], denda keterlambatan penyerahan pekerjaan [PED39], sumbangan pihak ketiga [PED40], pemberian hak atas tanah negara [PED41], pendapatan dan pengembalian dana bergulir [PED42] dan penerimaan potongan dari PT. Taspen [PED43] memberikan kontribusi terhadap lain-lain PAD yang sah [LPS] masing-masing sebesar 1.10 persen, 37.93 persen, 17.21 persen, 33.28 persen, 0.21 persen, 10.02 persen dan 0.26 persen. 
Tabel 8

Perkembangan dan Proyeksi Lain-Lain PAD Yang Sah [LPS]: PED37, PED38, PED39, PED40, PED41, PED42 dan PED43 Kabupaten Tapanuli Tengah [Ribu Rp]

\begin{tabular}{|c|rrrrrrrr|}
\hline TAHUN & PED37 & PED38 & PED39 & PED40 & PED41 & PED42 & PED43 & LPS \\
\hline 2003 & 10974.00 & 1467034.00 & 10520.30 & 1006224.00 & 1620.80 & 0.00 & 0.00 & 2496373.10 \\
2004 & 49199.00 & 350511.30 & 16387.66 & 1066271.00 & 0.00 & 9900.00 & 0.00 & 1492268.96 \\
2005 & 12125.00 & 582373.60 & 13634.90 & 795849.30 & 0.00 & 0.00 & 0.00 & 1403982.80 \\
2006 & 188576.00 & 1599635.00 & 0.00 & 1210458.00 & 0.00 & 0.00 & 0.00 & 2998669.00 \\
2007 & 0.00 & 2226619.00 & 149094.00 & 1381031.00 & 0.00 & 0.00 & 0.00 & 3756744.00 \\
2008 & 0.00 & 2612464.00 & 11845.00 & 1282599.00 & 0.00 & 35641.00 & 0.00 & 3942549.00 \\
2009 & 0.00 & 1610744.00 & 1373812.00 & 1269644.00 & 0.00 & 751977.00 & 17399.70 & 5023576.70 \\
2010 & 44418.34 & 1825357.19 & 1813178.99 & 1452084.52 & 10638.50 & 1053829.09 & 26647.07 & 6226153.71 \\
2011 & 16843.30 & 1950330.17 & 2211343.05 & 1585894.42 & 13703.70 & 1304329.63 & 33683.93 & 7116128.20 \\
2012 & 30765.00 & 2049467.00 & 2426573.03 & 1675547.90 & 27215.90 & 1458956.23 & 38500.92 & 7707025.97 \\
2013 & 44212.40 & 2172416.40 & 2683640.42 & 1773613.57 & 40334.20 & 1617290.27 & 42811.62 & 8374318.88 \\
2014 & 65441.00 & 2265770.19 & 2998792.88 & 1864317.74 & 62593.60 & 1812544.40 & 47892.00 & 9117351.81 \\
2015 & 82013.30 & 2375048.73 & 3230010.29 & 1985796.82 & 78813.30 & 1986130.04 & 53853.81 & 9791666.29 \\
\hline
\end{tabular}

Sumber: Data diolah dari Tapanuli Tengah Dalam Angka. BPS Kabupaten Tapanuli Tengah, 2003-2009 dan proyeksi dengan EViews 4.

Pos-pos bagi hasil pajak terdiri dari 4 [empat] pos pendapatan, yaitu pajak bumi dan bangunan, bea perolehan hak atas tanah dan bangunan, pajak penghasilan pasal 21 dan bagi hasil pajak kendaraan di atas air. Hasil estimasi pos-pos bagi hasil pajak adalah sebagai berikut:

$$
\begin{array}{ll}
\text { PED44 } & =14880952.210-24717710.600+1206673.460 \ln \text { PDRB } \\
\text { PED45 } & =1054914.955-24717710.600+1206673.460 \ln \text { PDRB } \\
\text { PED46 } & =535778.280-24717710.600+1206673.460 \ln \text { PDRB } \\
\text { PED47 } & =-359620.348-24717710.600+1206673.460 \ln \text { PDRB } \\
\text { BHP } & =\text { PED44 + PED45 + PED46 + PED47 }
\end{array}
$$

Dari persamaan ini diketahui bahwa komponen random effect pajak bumi dan bangunan [PED44] lebih tinggi dari komponen random effect bea perolehan hak atas tanah dan bangunan [PED45], pajak penghasilan pasal 21 [PED46] dan bagi hasil pajak kendaraan di atas air [PED47]. Artinya pengaruh khusus dari pos-pos bagi hasil pajak, perubahan teknologi, perubahan regulasi pemerintah dan perubahan eksternal mengindikasikan bahwa potensi pendapatan daerah dari pajak bumi dan bangunan lebih tinggi dari bea perolehan hak atas tanah dan bangunan, pajak penghasilan pasal 21 dan bagi hasil pajak kendaraan di atas air.

\section{Tabel 9}

Perkembangan dan Proyeksi Bagi Hasil Pajak [BHP]: PED44, PED45, PED46 dan PED47 Kabupaten Tapanuli Tengah [Ribu Rp]

\begin{tabular}{|c|rrrrr|}
\hline TAHUN & PED44 & PED45 & PED46 & PED47 & BHP \\
\hline 2003 & 9314066.000 & 839292.400 & 1199451.000 & 0.000 & 11352809.400 \\
2004 & 13414971.000 & 1130419.000 & 1628178.000 & 2620063.000 & 18793631.000 \\
2005 & 13144145.000 & 1943310.000 & 797248.300 & 0.000 & 15884703.300 \\
2006 & 21900711.000 & 1556691.000 & 1238668.000 & 0.000 & 24696070.000 \\
2007 & 21330023.000 & 2049838.000 & 1475857.000 & 0.000 & 24855718.000 \\
2008 & 16042217.000 & 1450234.000 & 333948.700 & 1852.250 & 17828251.950 \\
2009 & 17796417.000 & 3891408.000 & 2430012.000 & 0.000 & 24117837.000 \\
2010 & 18152675.800 & 4255502.874 & 2686010.023 & 62125.340 & 25156314.037 \\
2011 & 18364951.682 & 4618095.741 & 2966207.290 & 82000.200 & 26031254.913 \\
2012 & 18093873.437 & 4718059.656 & 3092516.325 & 100871.000 & 26005320.418 \\
2013 & 18676791.648 & 5002286.062 & 3252565.265 & 113356.000 & 27044998.975 \\
2014 & 18419888.912 & 5249679.853 & 3435715.401 & 127157.000 & 27232441.166 \\
2015 & 18803798.624 & 5383757.950 & 3637877.048 & 136831.000 & 27962264.622 \\
\hline
\end{tabular}

Sumber: Data diolah dari Tapanuli Tengah Dalam Angka. BPS Kabupaten Tapanuli Tengah, 2003-2009 dan proyeksi dengan EViews 4. 
Rerata elastisitas pendapatan dari pajak bumi dan bangunan [PED44], bea perolehan hak atas tanah dan bangunan [PED45], pajak penghasilan pasal 21 [PED46] dan bagi hasil pajak kendaraan di atas air [PED47] terhadap PDRB masing-masing sebesar 0.08 persen, 0.65 persen, 0.68 persen dan 0.94 persen. Artinya persentase peningkatan PDRB selalu lebih tinggi dari persentase peningkatan pajak bumi dan bangunan, bea perolehan hak atas tanah dan bangunan, pajak penghasilan pasal 21 dan bagi hasil pajak kendaraan di atas air atau inelastis. Hal ini mengindikasikan bahwa potensi pos-pos bagi hasil pajak relatif stabel sejalan dengan peningkatan potensi PDRB Kabupaten Tapanuli Tengah.

Perkembangan dan proyeksi pendapatan dari pajak bumi dan bangunan [PED44], bea perolehan hak atas tanah dan bangunan [PED45], pajak penghasilan pasal 21 [PED46] dan bagi hasil pajak kendaraan di atas air [PED47] memberikan kontribusi terhadap bagi hasil pajak [BPH] masing-masing sebesar 76.21 persen, 13.41 persen, 9.14 persen dan 1.25 persen.

Pos-pos bagi hasil bukan pajak terdiri dari 6 [enam] pos pendapatan, yaitu sumber daya alam kehutanan, sumber daya alam penambangan umum, sumber daya alam perikanan, sumber daya alam minyak bumi, sumber daya alam gas bumi dan bagi hasil cukai tembakau. Hasil estimasi pos-pos bagi hasil bukan pajak adalah sebagai berikut:

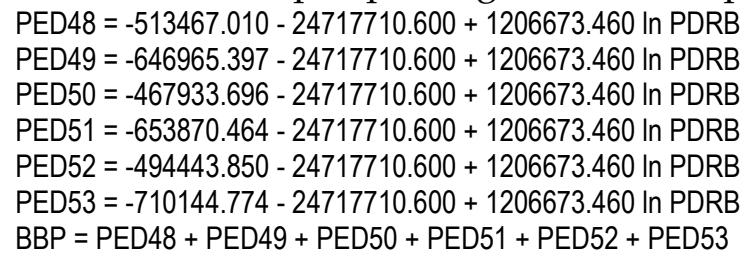

Dari persamaan ini diketahui bahwa komponen random effect sumber daya alam perikanan [PED50] lebih tinggi dari komponen random effect sumber daya alam gas bumi [PED52], sumber daya alam kehutanan [PED48], sumber daya alam penambangan umum [PED49], sumber daya alam minyak bumi [PED51] dan bagi hasil cukai tembakau [PED53]. Artinya pengaruh khusus dari pos-pos bagi hasil bukan pajak, perubahan teknologi, perubahan regulasi pemerintah dan perubahan eksternal mengindikasikan bahwa potensi pendapatan daerah dari sumber daya alam perikanan lebih tinggi dari potensi pendapatan daerah dari sumber daya alam gas bumi, sumber daya alam kehutanan, sumber daya alam penambangan umum, sumber daya alam minyak bumi dan bagi hasil cukai tembakau.

Rerata elastisitas pendapatan dari sumber daya alam kehutanan [PED48], sumber daya alam penambangan umum [PED49], sumber daya alam perikanan [PED50], sumber daya alam minyak bumi [PED51], sumber daya alam gas bumi [PED52] dan bagi hasil cukai tembakau [PED53] terhadap PDRB masing-masing sebesar 5.04 persen, 11.58 persen, 4.27 persen, 12.27 persen, 4.51 persen dan 29.05 persen. Artinya persentase peningkatan PDRB selalu lebih rendah dari persentase peningkatan pendapatan daerah dari sumber daya alam kehutanan, sumber daya alam penambangan umum, sumber daya alam perikanan, sumber daya alam minyak bumi, sumber daya alam gas bumi dan bagi hasil cukai tembakau atau elastis. Hal ini mengindikasikan bahwa potensi pos-pos bagi hasil bukan pajak relatif tinggi sejalan dengan peningkatan potensi PDRB Kabupaten Tapanuli Tengah.

\section{Tabel 10}

Perkembangan dan Proyeksi Bagi Hasil Bukan Pajak [BBP]: PED48, PED49, PED50, PED51, PED52 dan PED53 Kabupaten Tapanuli Tengah [Ribu Rp]

\begin{tabular}{|c|rrrrrrr|}
\hline TAHUN & PED48 & PED49 & PED50 & PED51 & PED52 & PED53 & BBP \\
\hline 2003 & 397616.50 & 0.00 & 339124.30 & 117025.00 & 1149097.00 & 0.00 & 2002862.80 \\
2004 & 119082.70 & 79843.28 & 157520.80 & 57113.30 & 438063.00 & 0.00 & 851623.08 \\
2005 & 285097.60 & 0.00 & 318317.10 & 77395.28 & 26215.35 & 0.00 & 707025.33 \\
2006 & 35335.35 & 143768.50 & 300879.80 & 118120.30 & 13477.51 & 0.00 & 611581.46 \\
2007 & 117458.80 & 151869.10 & 485474.00 & 62788.69 & 0.00 & 0.00 & 817590.59 \\
2008 & 254686.10 & 78280.04 & 140043.80 & 38505.58 & 1101.66 & 11415.90 & 524033.08
\end{tabular}




\begin{tabular}{|r|rrrrrrr|}
2009 & 299001.80 & 88174.54 & 96517.28 & 21004.19 & 18025.81 & 73188.40 & 595912.02 \\
2010 & 404112.85 & 128067.49 & 128971.48 & 30630.98 & 23586.54 & 111120.11 & 826489.44 \\
2011 & 485734.87 & 158118.02 & 154158.27 & 37994.58 & 28300.56 & 140112.19 & 1004418.49 \\
2012 & 544105.49 & 178233.80 & 170279.86 & 43017.23 & 32262.81 & 159855.93 & 1127755.12 \\
2013 & 590163.90 & 197594.91 & 185051.31 & 47405.79 & 33993.49 & 177703.88 & 1231913.27 \\
2014 & 653808.52 & 218481.28 & 201473.32 & 52662.65 & 37946.23 & 198798.60 & 1363170.60 \\
2015 & 715795.47 & 244987.95 & 223228.53 & 58966.37 & 41894.50 & 223020.70 & 1507893.53 \\
\hline
\end{tabular}

Sumber: Data diolah dari Tapanuli Tengah Dalam Angka. BPS Kabupaten Tapanuli Tengah, 2003-2009 dan proyeksi dengan EViews 4.

Perkembangan dan proyeksi pendapatan dari sumber daya alam kehutanan [PED48], sumber daya alam penambangan umum [PED49], sumber daya alam perikanan [PED50], sumber daya alam minyak bumi [PED51], sumber daya alam gas bumi [PED52] dan bagi hasil cukai tembakau [PED53] memberikan kontribusi terhadap bagi hasil bukan pajak [BBP] masing-masing sebesar 37.07 persen, 13.58 persen, 24.82 persen, 6.48 persen, 10.37 persen dan 7.68 persen.

Pos-pos bagian lain-lain penerimaan yang sah terdiri dari 5 [lima] pos pendapatan daerah, yaitu pajak kendaraan bermotor/bea balik nama kendaraan bermotor, pajak bahan bakar kendaraan bermotor, pajak pengambilan dan pemanfaatan ABT dan APU, bantuan keuangan dari provinsi dan hibah dari provinsi. Hasil estimasi dari pos-pos bagian lainlain penerimaan yang sah adalah sebagai berikut:

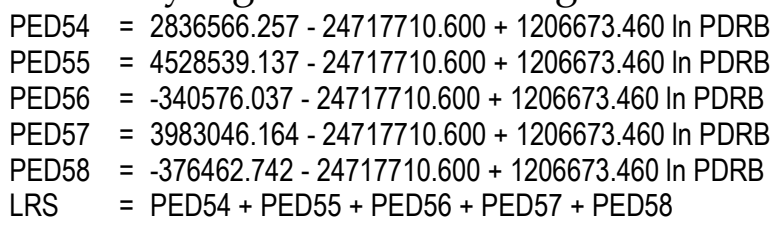

Dari persamaan ini diketahui bahwa komponen random effect pajak bahan bakar kendaraan bermotor [PED55] lebih tinggi dari komponen random effect bantuan keuangan dari provinsi [PED57], pajak kendaraan bermotor/bea balik nama kendaraan bermotor [PED54], pajak pengambilan dan pemanfaatan ABT dan APU [PED56] dan hibah dari provinsi [PED58]. Artinya pengaruh khusus dari pos-pos bagian lain-lain penerimaan yang sah, perubahan teknologi, perubahan regulasi pemerintah dan perubahan eksternal mengindikasikan bahwa potensi pendapatan daerah dari pajak bahan bakar kendaraan bermotor lebih tinggi dari potensi bantuan keuangan dari provinsi, pajak kendaraan bermotor/bea balik nama kendaraan bermotor, pajak pengambilan dan pemanfaatan ABT dan APU serta hibah dari provinsi.

\section{Tabel 11}

Perkembangan dan Proyeksi Bagian Lain-Lain Penerimaan Yang Sah [LRS]: PED54, PED55, PED56, PED57 dan PED58 Kabupaten Tapanuli Tengah [Ribu Rp]

\begin{tabular}{|c|rrrrrr|}
\hline TAHUN & PED54 & PED55 & PED56 & PED57 & PED58 & LRS \\
\hline 2003 & 2502161.00 & 763534.60 & 0.00 & 2910999.00 & 0.00 & 6176694.60 \\
2004 & 3125717.00 & 1274282.00 & 211249.60 & 1514835.00 & 0.00 & 6126083.60 \\
2005 & 4784164.00 & 2768198.00 & 457003.90 & 1894950.00 & 0.00 & 9904315.90 \\
2006 & 3044799.00 & 3935945.00 & 578400.00 & 4037500.00 & 0.00 & 11596644.00 \\
2007 & 2551117.00 & 4140532.00 & 505622.30 & 5741660.00 & 0.00 & 12938931.30 \\
2008 & 4724879.00 & 18142874.00 & 554223.60 & 5747854.00 & 0.00 & 29169830.60 \\
2009 & 5025043.00 & 6980053.00 & 453270.70 & 12209008.00 & 2500000.00 & 27167374.70 \\
2010 & 5325423.67 & 7552496.91 & 585284.64 & 12588648.79 & 3104526.21 & 29156380.22 \\
2011 & 5524825.15 & 7289812.90 & 679734.30 & 13087260.56 & 3742723.44 & 30324356.36 \\
2012 & 5647017.60 & 7549416.12 & 737279.14 & 13074495.23 & 4032876.47 & 31041084.55 \\
2013 & 5838747.04 & 8072604.82 & 807296.06 & 13773448.79 & 4449676.37 & 32941773.09 \\
2014 & 6040565.08 & 8225127.92 & 869346.61 & 14304605.49 & 5013707.90 & 34453353.00 \\
2015 & 6081112.17 & 8027539.45 & 950620.51 & 14057501.12 & 5246571.81 & 34363345.05 \\
\hline
\end{tabular}

Sumber: Data diolah dari Tapanuli Tengah Dalam Angka. BPS Kabupaten Tapanuli Tengah, 2003-2009 dan proyeksi dengan EViews 4. 
Rerata elastisitas pendapatan dari pajak kendaraan bermotor/bea balik nama kendaraan bermotor [PED54], pajak bahan bakar kendaraan bermotor [PED55], pajak pengambilan dan pemanfaatan ABT dan APU [PED56], bantuan keuangan dari provinsi [PWD57] dan hibah dari provinsi [PED58] terhadap PDRB masing-masing sebesar 0.34 persen, 0.23 persen, 2.97 persen, 0.26 persen dan 3.36 persen. Artinya persentase peningkatan PDRB selalu lebih rendah dari persentase peningkatan pendapatan daerah dari pajak pengambilan dan pemanfaatan ABT dan APU dan hibah dari provinsi atau elastis. Sebaliknya persentase peningkatan PDRB selalu lebih tinggi dari persentase peningkatan pajak kendaraan bermotor/bea balik nama kendaraan bermotor, pajak bahan bakar kendaraan bermotor dan bantuan keuangan dari provinsi atau inelastis. Hal ini mengindikasikan bahwa potensi pospos bagian lain-lain penerimaan yang sah relatif tinggi sejalan dengan peningkatan potensi PDRB Kabupaten Tapanuli Tengah.

Perkembangan dan proyeksi pendapatan dari pajak kendaraan bermotor/bea balik nama kendaraan bermotor [PED54], pajak bahan bakar kendaraan bermotor [PED55], pajak pengambilan dan pemanfaatan ABT dan APU [PED56], bantuan keuangan dari provinsi [PWD57] dan hibah dari provinsi [PED58] memberikan kontribusi terhadap bagian lain-lain penerimaan yang sah [LRS] masing-masing sebesar 18.02 persen, 24.53 persen, 2.29 persen, 42.52 persen dan 12.65 persen.

Potensi pendanaan peningkatan kapasitas yang berkelanjutan bersumber dari potensi pendapatan daerah, sedangkan potensi pendapatan daerah [PED] bersumber dari potensi pendapatan asli daerah [PAD], bagi hasil pajak [BHP], bagi hasil bukan pajak [BBP] dan lainlain penerimaan yang sah [LRS]. Di lain pihak, potensi pendapatan asli daerah bersumber dari potensi pajak daerah [PJD], retribusi daerah [RTD], bagian laba BUMD [LBU] dan lainlain PAD yang sah [LPS].

\section{Tabel 12}

Perkembangan dan Proyeksi Pendapatan Asli Daerah [PAD]: PJD, RTD, LBU dan LPS Kabupaten Tapanuli Tengah [Ribu Rp]

\begin{tabular}{|c|rrrrr|}
\hline TAHUN & PJD & RTD & LBU & LPS & PAD \\
\hline 2003 & 1642895.400 & 1192605.900 & 0.000 & 2496373.100 & 5331874.400 \\
2004 & 1807293.600 & 935411.070 & 0.000 & 1492268.960 & 4234973.630 \\
2005 & 1808888.350 & 867468.270 & 137003.800 & 1403982.800 & 4217343.220 \\
2006 & 1596269.020 & 918824.150 & 2178073.400 & 2998669.000 & 7691835.570 \\
2007 & 3289130.950 & 1459246.250 & 1738825.000 & 3756744.000 & 10243946.200 \\
2008 & 3215344.300 & 1836460.270 & 2306383.800 & 3942549.000 & 11300737.370 \\
2009 & 3623566.200 & 2294525.050 & 2372090.000 & 5023576.700 & 13313757.950 \\
2010 & 4163235.523 & 3317882.577 & 2739398.136 & 6226153.710 & 16446669.946 \\
2011 & 4555473.942 & 3921309.936 & 2960437.313 & 7116128.202 & 18553349.393 \\
2012 & 4810550.513 & 4445637.270 & 3063962.270 & 7707025.975 & 20027176.028 \\
2013 & 5129906.398 & 4944365.177 & 3353037.298 & 8374318.883 & 21801627.756 \\
2014 & 5412732.003 & 5541025.870 & 3501513.374 & 9117351.811 & 23572623.058 \\
2015 & 5706458.179 & 6171040.270 & 3686002.034 & 9791666.287 & 25355166.770 \\
\hline
\end{tabular}

Sumber: Data diolah dari Tapanuli Tengah Dalam Angka. BPS Kabupaten Tapanuli Tengah, 2003-2009 dan proyeksi dengan EViews 4.

Perkembangan dan proyeksi pajak daerah [PJD], retribusi daerah [RTD], bagian laba Badan Usaha Milik Daerah [LBU] dan lain-lain PAD yang sah [LPS] memberikan kontribusi terhadap pendapatan asli daerah [PAD] masing-masing sebesar 24.30 persen, 21.61 persen, 15.79 persen dan 38.30 persen. Seberapa besar peningkatan pendapatan daerah sebagai sumber pendanaan peningkatan kapasitas pemerintah daerah ditargetkan pada periode waktu 2010-2015? 


\section{Tabel 18}

Perkembangan dan Proyeksi Pendapatan Daerah [PED]: PAD, BHP, BBP dan LRS Kabupaten Tapanuli Tengah [Ribu Rp]

\begin{tabular}{|c|rrrrr|}
\hline TAHUN & PAD & BHP & BBP & LRS & PED \\
\hline 2003 & 5331874.400 & 11352809.400 & 2002862.800 & 6176694.600 & 24864241.200 \\
2004 & 4234973.630 & 18793631.000 & 851623.080 & 6126083.600 & 30006311.310 \\
2005 & 4217343.220 & 15884703.300 & 707025.330 & 9904315.900 & 30713387.750 \\
2006 & 7691835.570 & 24696070.000 & 611581.460 & 11596644.000 & 44596131.030 \\
2007 & 10243946.200 & 24855718.000 & 817590.590 & 12938931.300 & 48856186.090 \\
2008 & 11300737.370 & 17828251.950 & 524033.079 & 29169830.600 & 58822852.999 \\
2009 & 13313757.950 & 24117837.000 & 595912.020 & 27167374.700 & 65194881.670 \\
2010 & 16446669.946 & 25156314.037 & 826489.440 & 29156380.224 & 71585853.647 \\
2011 & 18553349.393 & 26031254.913 & 1004418.493 & 30324356.356 & 75913379.155 \\
2012 & 20027176.028 & 26005320.418 & 1127755.116 & 31041084.545 & 78201336.107 \\
2013 & 21801627.756 & 27044998.975 & 1231913.266 & 32941773.087 & 83020313.084 \\
2014 & 23572623.058 & 27232441.166 & 1363170.599 & 34453353.001 & 86621587.824 \\
2015 & 25355166.770 & 27962264.622 & 1507893.533 & 34363345.055 & 89188669.980 \\
\hline
\end{tabular}

Sumber: Data diolah dari Tapanuli Tengah Dalam Angka. BPS Kabupaten Tapanuli Tengah, 2003-2009 dan proyeksi dengan EViews 4.

Pendapatan asli daerah [PAD] sebesar Rp 13.313.757.950 pada tahun 2009 diproyeksikan naik menjadi Rp 25.355.166.770 pada tahun 2015 atau rerata naik 10.74 persen atau $\mathrm{Rp}$ 2.007.775.629 per tahun. Demikian juga bagi hasil pajak [BHP] sebesar Rp 24.117.837.000 pada tahun 2009 diproyeksikan naik menjadi Rp 27.962.264.622 pada tahun 2015 atau rerata naik 2.47 persen atau Rp 640.737 .937 per tahun. Bagi hasil bukan pajak [BBP] sebesar Rp 595.912.020 pada tahun 2009 diproyeksikan naik menjadi Rp 1.507.893.533 pada tahun 2015 atau rerata naik 15.47 persen atau Rp 151.996.919 per tahun.

Demikian juga lain-lain penerimaan yang sah [LRS] sebesar Rp 27.167.374.700 diproyeksikan naik menjadi Rp 34.363.345.055 pada tahun 2015 atau rerata naik 3.92 persen atau $R p$ 1.199.328.392 per tahun. Dengan demikian pendapatan daerah [PED] sebesar Rp 65.194.881.670 pada tahun 2009 diproyeksikan naik menjadi Rp 89.188.669.980 pada tahun 2015 atau rerata naik 5.22 persen atau Rp 3.998.964.718 per tahun. Pemerintah daerah Kabupaten Tapanuli Tengah dapat menggunakan 25 persen potensi peningkatan pendapatan daerah ini untuk pendanaan peningkatan kapasitas yang berkelanjutan.

Proyeksi peningkatan pendapatan daerah [PED] sebesar 5.22 persen per tahun lebih rendah dari proyeksi peningkatan PDRB atas dasar harga berlaku sebesar 11.72 persen per tahun. Hal ini merupakan indikator bahwa pertumbuhan pendapatan daerah pemerintah Kabupaten Tapanuli Tengah selalu lebih rendah dari pertumbuhan PDRB atas dasar harga berlaku. Proyeksi peningkatan pendapatan daerah ini menjelaskan bahwa potensi sumbersumber pendanaan peningkatan kapasitas yang berkelanjutan pemerintah daerah Kabupaten Tapanuli Tengah masih cukup potensial.

\section{KESIMPULAN}

Model proyeksi PDRB Kabupaten Tapanuli Tengah tang ditentukan okeh waktu atau trend sebagai variabel bebas sangat signifikan. Model ini sangat sederhana akan tetapi dapat memperkirakan PDRB secara rasional dan sesuai dengan fakta empiris. Rerata proyeksi pertumbuhan PDRB atas dasar harga berlaku dari 2009-2015 sebesar 11.72 persen atau PDRB naik dari Rp 1.990.000.000.000 pada tahun 2009 menjadi Rp 4.020.000.000.000 pada tahun 2015. Nilai proyeksi PDRB ini merupakan variabel kebijakan untuk proyeksi pos-pos pendapatan daerah.

Sebagai variabel bebas terhadap pos-pos pendapatan daerah menghasilkan model dalam bentuk lin-log random effect sangat signifikan dan memenuhi asumsi normalitas dan non autokorelasi, sehingga model dalam bentuk lin-log random effect sangat valid digunakan 
sebagai alat proyeksi pos-pos pendapatan daerah. Model dalam bentuk lin-log random effect mempunyai konstanta bersama negatip Rp 24.717.710.600 dan koefisien In PDRB terhadap PED sebesar 1.206.673.460. Nilai kontanta bersama ini menjelaskan rerata masing-masing pos-pos pendapatan daerah, sedangkan pengaruh gangguan acak atau random effect menjelaskan pengaruh khusus perubahan teknologi, regulasi pemerintah dan perubahan eksternal terhadap pos-pos pendapatan daerah Kabupaten Tapanuli Tengah.

\section{DAFTAR PUSTAKA}

Barro, R. J. 1997. Macroeconomics. Third Edition. Cambridge: The MIT Press.

Barro, R. J. and X. Sala-I-Martin. 1995. Economic Growth. Singapore: McGraw-Hill International Editions.

Blanchard, O. 2000. Macroeconomics. Second Edition. New Jersey: Prentice-Hall, Inc.

Blanchard, O. and S. Fischer. 1989. Lecture on Macroeconomics. Cambrige: MIT Press.

Blanchard, O. and L. H. Summers. 1984. "Perspective on High Interest Rate". Brooking Papers on Economic Activity 2: Pp. 273-334.

Doepke, M., A. Lehnert and A. W. Sellgren. 1998. Macroeconomics. Chicago, Illinois.

Dornbusch, R., S. Fischer and R. Startz. 1998. Macroeconomics. Seventh Edition. Boston: The McGraw-Hill Companies Inc.

Gillis, M. et. al. 1996. Economics of Development. Fourth Edition. New York: W. W. Norton and Company.

Greene, W. H. 1997. Econometric Analysis. Third Edition. New York: Prentice-Hall International Editions.

Gujarati, D. 2003. Basic Econometrics. Fourth Edition. New York: McGraw-Hill Companies.

Harberger, A. C. 1998. "A Vision of the Growth Process". The American Economic Review: Pp. 1-32.

Herrick, B. and C. P. Kindleberger. 1983. Economic Development. Singapore: McGraw-Hill International Editions.

Jun, J. 1994. “How Taxation Affects Foreign Direct Investment (Country - Specific Evidence)". Policy Working Paper 1490: The World Bank.

Keputusan Meneteri Dalam Negeri Nomor 29 Tahun 2002 tentang Pedoman Pengurusan, Pertanggungjawaban dan Pengawasan Keuangan Daerah serta Tata Cara Penyusunan APBD, Pelaksanaan Tata Usaha Keuangan Daerah dan Perhitungan APBD.

Mankiw, N. G. 1994. Macroeconomics. Second Edition. New York: Worth Publishers Inc.

Manurung, J., A. H. Manurung dan F. D. Saragih. 2005. Ekonometrika: Teori dan Aplikasi. Jakarta: PT. Elex Media Komputindo. Kelompok Gramedia.

Mardiasmo. 2002. Akuntansi Sektor Publik. Yogyakarta: Penerbit Andi.

Megantara, A., D. Iskandar dan K. Slamet. 2006. Manajemen Perbendaharaan Pemerintahan: Aplikasi di Indonesia. Jakarta: Lembaga Pengkajian Keuangan Publik dan Akuntansi Pemerintah (LPKPAP). Badan Pendidikan dan Pelatihan Keuangan Departemen Keuangan RI.

Mulyana, B., Subkhan dan K. Slamet. 2006. Keuangan Daerah: Perspektif Desentralisasi Fiskal dan Pengelolaan APBD diIndonesia. Jakarta: Lembaga Pengkajian Keuangan Publik dan Akuntansi Pemerintah, Badan Pendidikan dan Pelatihan Keuangan. Departemen Keuangan RI.

Peraturan Pemerintah Nomor 105 Tahun 2000 tentang Pengelolaan dan Pertanggungjawaban Keuangan Daerah.

Peraturan Menteri Dalam Negeri Nomor 26 Tahun 2006 tentang Pedoman Penyusunan APBD

Peraturan Pemerintah Nomor 65 Tahun 2001 tentang Pajak Daerah.

Peraturan Pemerintah Nomor 66 Tahun 2001 tentang Retribusi Daerah. 
Peraturan Pemerintah Nomor 54 Tahun 2005 tentang Pinjaman Daerah.

Peraturan Pemerintah Nomor 55 Tahun 2005 tentang Dana Pembangunan.

Pindyck, R.S. and D. L. Rubinfeld. 1991. Econometric Models and Economic Forecasts. Third Edition. Singapore: McGraw-Hill International Edition.

Rodriquez, A. 1993. “The Debt Money Ratio: What Are Limits ?". Pp. 131-150 in M. Boldassarri. et.al. (eds). Debt, Deficit and Economic Performance. Rome: St. Martin's Press.

Romer, D. 1996. Advance Macoreoconomics. Singapore: McGraw-Hill International Editions.

BPS Kabupaten Tapanuli Tengah. 2010. Tapanuli Tengah Dalam Angka.

Undang-Undang Nomor 32 Tahun 2004 tentang Pemerintahan Daerah.

Undang-Undang Nomor 7 Tahun 1983 tentang Pajak Penghasilan dan telah diubah dengan Undang-Undang Nomor 17 Tahun 2000.

Undang-Undang Nomor 12 Tahun 1985 tentang Pajak Bumi dan Bangunan dan telah diubah dengan Undang-Undang Nomor 12 Tahun 1994.

Undang-Undang Nomor 1 Tahun 1998 tentang Bea Perolehan Atas Tanah dan Bangunan.

Undang-Undang Nomor 20 Tahun 2000 tentang Bea Perolehan Hak Atas Tanah dan Bangunan.

Undang-Undang Nomor 34 Tahun 2000 tentang Pajak Daerah dan Retribusi Daerah.

Undang-Undang Nomor 33 Tahun 2004 tentang Perimbangan Keuangan antara Pemerintah Pusat dan Daerah.

Zikmund, W. G. 1997. Business Research Methods. Fith Edition. Florida: The Dryden Press Harcourt Brace College Publishers. 